POLIICALECONOMY RESARCH INSTIUIE

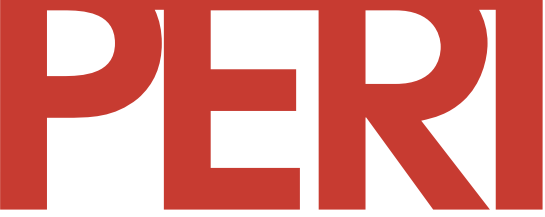

University of Massac husetts Amherst

\title{
Globalization and the Fiscal Autonomy of the State
}

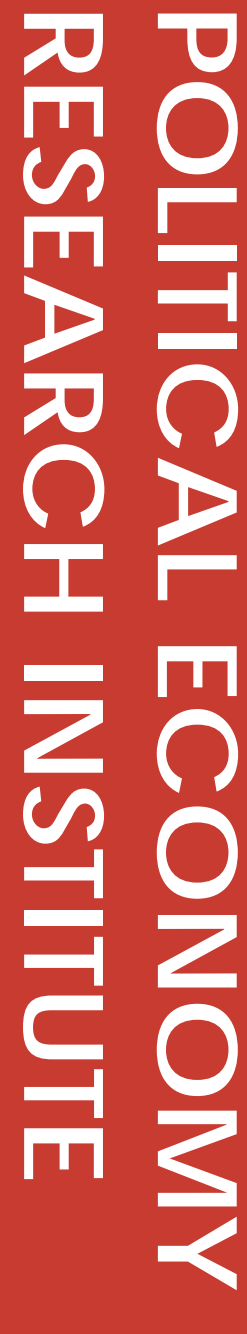

J. Mohan Rao

2001

10th floor Thompson Hall

University of Massachusetts

Amherst, MA, 01003-7510

Telephone: (413) 545-6355

Facsimile: (413) 545-2921

Email:peri@ec onsumassedu Wabsite:

hthp:/ / mww.umassedu/peil

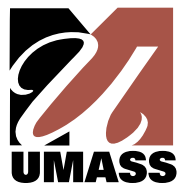




\title{
Globalization and the Fiscal Autonomy of the State
}

\author{
J. Mohan Rao* \\ University of Massachusetts at Amherst
}

March 1999

Background Paper for the Human Development Report 1999

Human Development Report Office,

UNDP, New York.

* The author is grateful to Selim Jahan, Sakiko Fukuda-Parr, Laura Mourino-Casas and Pablo Rodas for help that made this research possible and to participants at the October 1999 UNDP conference on globalization for their comments 


\section{Contents}

1. Introduction

2. The Fiscal Constraint Under Economic Liberalization

3. Tax Structure, Globalization and Revenue Effects

4. Financial Liberalization and the Fiscal Squeeze

5. Infrastructure and Human Development Impacts

6. Conclusion 


\section{Introduction}

Public finance in less developed countries is the focal point - both as source and destination - of many of the dilemmas and conflicts posed by development. Revenue mobilization for the allocative, distributive and stabilization functions of the state is severely constrained by the narrowness and instability of the tax base. The latter, in turn, is the result of political constraints rooted in socioeconomic inequalities, economic constraints arising from the structures of production and trade, and administrative constraints reflecting a weakly developed state apparatus. As a consequence, public infrastructure and human development expenditures, which are among the most effective vehicles available for reaching the poor and promoting growth at the same time, persistently fall short of socially desired levels. While fiscal constraints do not always reflect the need to finance current and capital outlays for development, public investment is often the first victim of fiscal troubles. Moreover, states must typically resort to modes of taxation and budget financing that violate accepted canons of economic efficiency and 'good' macroeconomic policy. For much the same reasons - political, economic and administrative - social transfers through the budget must also rely on inefficient and leaky buckets. Hence, from both the expenditure and revenue sides, public squalor exacerbates private squalor.

Overcoming fiscal constraints is both cause and consequence of a cumulative process of internal integration. The intra-national division of labor, as Adam Smith observed, is limited by the extent of the market: specialization is a public good producing external benefits that are jointly consumed. In addition, public infrastructure investment (in transport and communications, education, research, extending the land frontier, etc.) raises productivity both directly and by extending the home 
market while, the development of state institutions (enactment and enforcement of laws, tax collecting machinery, maintaining order, etc.) serves to expand the state's revenues. As the market expands, the costs of running the state and delivering infrastructure services fall and state revenues increase at the same time. These make possible an increased supply of public goods and services which further extends the home market. Hence, the expansion of the home market and modern state formation feed on each other in cumulative fashion and add to national competitiveness and productivity. Similarly, while an initially significant productivity lag seems almost inevitable in agriculture relative to industry and in informal activities relative to the formal, a successful process of internal integration must dissolve these lags progressively over time. Such internal convergence and integration is both the hallmark and the principal mechanism of development. It is also the basis for raising national competitiveness and achieving international convergence.

Consistent with this formulation, states have played a pivotal role in capitalist transformations throughout the world. The development of the market system has required the simultaneous development of institutions, including the state itself, to support it. Late developers have found it necessary to fashion state institutions and policies that are more actively engaged, both qualitatively and quantitatively, in the development process. Nurturing local development against competing global forces has become a progressively more delicate affair. Strategic direction of the economy, macroeconomic management to secure internal and external balance, and selective engagement in global markets to exploit its opportunities and thwart its constraints have been added to the more traditional tasks of establishing new forms of property relations and associated legal and enforcement systems, ensuring order, supplying infrastructural and educational services and, above all, resolving the fundamental 
political conflicts arising in the process of constructing a market system.

But internal integration is not a mechanistic process that is guaranteed to succeed. It requires coordinated structural change and investments, and hence a major role for public policy and public finance. This is the reason for ensuring that the conditions in which national economies are integrated with global markets do not jeopardize national autonomy. Globalization or external integration of weakly integrated national economies forces unpleasant tradeoffs between the requirements of internal integration and those of external integration. In a globalizing world, the problem for developing countries is not so much that external integration threatens internal disintegration. Rather, external integration may abort a healthy process of internal integration that is practically a defining element in successful development. At the very least, management of these tradeoffs requires a modicum of national autonomy which can only be sustained with a measure of fiscal autonomy from the pressures of globalization.

At the same time, a half century of experience shows that it does not follow, merely from demonstrating the developmental value of national autonomy, that the state will exercise its autonomy successfully. Modern state formation has been no less problematic than the process of economic modernization or development, as the history of western Europe reveals. Constraints originate both from conflicts in civil society and from failures within the state. In many parts of the developing world, the four or five decades following the retreat of colonialism have seen intense state-building activity and attempted modernization. The complementarity between these processes noted above does not imply that they will be successfully implemented. The failures and reversals (as also the successes) in this effort cannot be understood except in political terms i.e., in terms of the conflicts generated by the 
social embeddedness of both state and economy.

Yet, economic and ideological compulsions arising from the very lack of economic success has strengthened a rather optimistic vision of development through globalization. Liberalized markets, in this view, are the optimal route to both internal and external integration. This view is based on both economic and political arguments. On the economic side, this is illustrated by the gains from international trade. The main instruments include trade policy reform (dismantling quantitative restrictions, reducing tariff rates and ensuring currency convertibility), openness to capital and technology flows, unhindered flow of domestic investment and labor across sectors (flexibility and free exit), financial reform to permit market-determination of investment and saving, and public sector disinvestment. On the political side, it is argued that the global market provides the ideal antidote to political cupidity and stupidity since states, when not bound to a minimalist agenda by the global market system, are liable to be captured by sheltered special interests or fall victim to erroneous ideas. Hence, globalization is not merely useful for extending the gains from trade; it is in fact the most effective means available to achieve the minimalist state, thus also avoiding the much larger losses from "rentseeking". Clearly, the most important implication of this policy agenda is that internal and external integration are strictly complementary.

In keeping with this orthodox formulation, the fiscal effects of liberalization have received far less attention in the literature than their 'real' effects on exports, resource allocation across sectors, and on the trade or external balance. By contrast, this paper focusses on the fiscal impact of globalization on the theory that government budgets have been a principal site at which the tradeoffs between internal and external integration make themselves felt. Using cross-country evidence for the period 1970-96, 
the paper explores the revenue and expenditure implications of trade and financial liberalization. Such liberalization has been effected, particularly in the 1980s and 1990s, not only through the structural adjustment packages and conditionalities of international lending institutions but also by reform efforts undertaken by countries fearful of losing access to global markets and capital flows.

The plan of the paper is as follows. Section 2 provides an overview of trends in economic openness and in fiscal aggregates. It also suggests a theoretical basis for understanding the emergence of fiscal constraints in less developed countries (LDCs) from the viewpoint of both economic growth and human development. Section 3 analyzes trends in the tax structure of LDCs during the period of liberalizing reforms. Apart from a comparison in tax structures across levels of development, the main object of the analysis is the decline in government revenues from trade following tariff and export tax rate reductions. Decomposition of revenue effects shows that trade failed to rise sufficiently to compensate for the rate reductions in most countries. Section 4 looks at the fiscal effects of rising national debts and financial liberalization particularly in low-income countries. A crude aggregate index of the fiscal impact flowing from liberalization - in the form of trade revenue losses and rising public debt-servicing burdens - suggests that globalization has indeed produced a fiscal squeeze for LDC governments. Section 5 looks at the effects of the fiscal squeeze on government investments in public capital and human capital. International experience in this respect seems varied reflecting perhaps the diverse policy responses to the fiscal squeeze and the initial conditions faced. Nevertheless, the crossnational evidence shows that the fiscal squeeze has dampened overall (physical and human capital) investment in developing countries. The section ends with a consideration of the redistributive effects of globalization and their implications for maintaining or strengthening feasible social safety nets. Section 6 
concludes the paper.

\section{The Fiscal Constraint Under Economic Liberalization}

For any given configuration of political and social forces, policy maneuverability in LDCs is severely restricted by the feasible instruments of policy. Hence, policy tradeoffs are sharper and policymakers must worry not only about the 'direct' effects of policy changes on social groups but also the gap between the resource demands needed to engineer compromises and the fiscal resources available.

Put differently, fiscal actions or policies must seek not merely to close social-political gaps but also ensure that fiscal gaps are not widened in the process. When countries are more or less chronically confronted with a fiscal gap, policy change has to be particularly sensitive in this regard. In particular, changes that promise overall social gain may nonetheless provide no room for fiscally-mediated compensation policies or may even reduce the room available. Such countries may properly be said to lack fiscal autonomy.

In standard neoclassical economics, the allocation of resources between the public and private sectors (hence the choice of both tax and expenditure policies) is seen to derive from an optimizing calculus. Such a calculus is unproblematic if it is assumed that there exists a well-defined social welfare function and that needed resource transfers between the public and private sectors (or within the private economy) can be arranged through non-distortionary lump-sum transfers. These assumptions ensure that a social contract is costlessly defined and costlessly implemented. Fiscal autonomy here is absolute and the budget is a first-best outcome.

A dose of realism may be added to this formulation with the recognition that real-world taxes to finance the budget are bound to distort resource allocation and that there will also be costs in reaching a 
social contract. In other words, resource allocation between the public and private sectors entails tradeoffs that go beyond the purely technologically-defined opportunity costs. These additional tradeoffs arise essentially from incentive effects, the transactions costs of political bargaining, and the costs of administration to effect needed taxes and transfers. If it is assumed that these added tradeoffs in the budget are essentially calculable, even if only through a social-political bargaining process, then, the budget will be a second-best outcome.

From such a viewpoint, therefore, the fiscal autonomy of the state, even allowing for economic feedbacks, can never be compromised. At worst, fiscal autonomy may be monopolized by a narrow interest group or by a runaway state not answerable to civil society, a particular outcome of the `social contract' rather than the absence of a contract. There can be no room, in this conception, for economic forces to directly constrain fiscal maneuverability. Even openness to liberalized markets and globalization that narrowly limit state options is seen as a policy choice.

In practice, LDC governments confront financing constraints of greater or less severity in pursuing otherwise feasible growth-enhancing or human development-enhancing policies. While these may be formally seen, as above, to flow from the prevailing political-economic equilibrium, the very existence of fiscal constraints suggests that there are multiple equilibria. The economy may get stuck in a bad equilibrium when political and economic factors reinforce each other. Suppose, for example, that equilibrium A produces a more equitable, human development-enhancing outcome compared to equilibrium B. Assume also that A requires a larger budget than B but that political-economic factors, by constraining the budget, make B the prevailing, self-enforcing equilibrium. If new economic policy 
choices serve to relax the fiscal constraint, the economy may then be able to move to equilibrium $\mathrm{A}^{1}$.

A fiscal constraint arises in developing countries chiefly from the facts that the tax base is usually narrow and there are strict limits to how far tax rates can be raised on that narrow base when adjustment involves the whole economy. LDCs tend to have a relatively large share of economic activity in low-taxed sectors such as agriculture, informal industry and services; in addition, a significant part of the potential revenue at legislated rates fails to be realized on account of collection problems, corruption and evasion. The problem also has a dynamic dimension. As an economy grows, its fiscal requirements are also expected to grow. This association has causal factors going both ways. A larger economy is easier to tax but a larger economy also require larger fiscal outlays. This does not necessarily mean that economic growth and government budget outlays can grow in a smooth and balanced fashion. There are important lags in the redesigning of the fiscal structure since political and administrative obstacles must be overcome. Conversely, there may also be important leads from fiscal effort to economic growth i.e., growth itself may depend on a rise in fiscal outlays. Such dynamic fiscal lags and leads can conspire to hold back growth itself.

${ }^{1}$ To be sure, moving out of the fiscally-constrained initial equilibrium cannot be a matter only of the right policy choice being technically feasible. But an 'outside' observer or policy analyst ought to take into account how, in economic terms, policy recommendations relax or reinforce the constraint, and how, in political terms, they enlarge or constrict the room for left-out groups in society to participate in the process that determines budgets and to make their valuations relevant. 
Apart from limits on taxation, other ways of financing government deficits also quickly run into diminishing political and economic returns. Foreign financing, which mostly takes the form of grants and loans to governments, cannot be directly controlled by the borrowing government. They also come with conditionalities that may narrow policy choices and fiscal autonomy. Similarly, domestic finance is limited by the underdeveloped state of domestic financial markets on the one hand and the inflationary potential of bank financing on the other.

Following the world-wide slowdown in growth and rise in interest rates, many developing countries emerged from the 1980s with the need to make massive external transfers on account of accumulated debt. At the same time, a large internal transfer had to be effected since much of this debt was incurred on public account whilst export earnings that would pay for it was mostly private. Apart from the narrow fiscal choices available to effect this internal transfer, the adjustment process itself tended to be contractionary with attendant losses rather than gains in public revenue. As a consequence, fiscal retrenchment became the order of the day in most countries undergoing adjustment. Reductions in the non-interest part of expenditure tended to hurt public capital expenditure with further growth-reducing effects.

Conditionalities accompanying accommodation by creditors included a general program of market liberalization. Thus, many developing economies have engaged in external liberalization while faced with balance-of-payments and fiscal constraints. In particular, trade liberalization - which has almost invariably reduced public revenues - has had to be undertaken alongside public expenditure reductions and/or non-trade-based tax increases. Moreover, devaluations undertaken as part of the reform package have raised government debt service obligations. Trade and exchange reforms thus 
added a further important fiscal burden leading to cuts in domestic capital accumulation. It is in this sense that adjustment to debt and adjustment to liberalization have had major fiscal, growth and redistributive effects. As persistent fiscal deficits added to the public debt, financial liberalization and increased reliance on foreign financing of public deficits did not help since interest rates on market borrowing by states rose to add to the burden.

The quality of fiscal adjustment is a matter of sustaining, indeed raising, the levels of public capital investment on the one hand and of widening the tax net on the other. Liberalization tends to militate against both objectives in the short to medium term. When this is coupled with the argument above that the policy regime reinforces politics and vice versa, liberalization aimed at globalization may also produce adverse longer-term impacts. While it might be supposed that once the transition is weathered, growth cannot decline and possibly rise, the fiscal constraint has remained at the center of the dilemma of how to effect the transition without hurting growth prospects.

For these reasons, the analysis of fiscal trends that follows must be placed in the context of growing globalization. Table 1 summarizes the broad picture of economic globalization in terms of exports plus imports relative to GDP; the taxation of trade whether for protective or fiscal purposes; and the flow of net foreign direct investment (FDI). T rade openness may be measured directly in terms of the trade share in GDP and also in terms of a T rade Index which is constructed from the trade share after controlling for the facts that richer countries are more open and so are smaller countries (Rao, 1998). T rade taxation is indicated both ex ante i.e. based on weighted average published tariff rates circa 1992, and as ex post realized tax rates i.e. total trade tax revenues divided by total trade (hereafter the "trade tax ratio"). The trade ratio and the Trade 
Index are highly correlated, and so are the ex ante import tariff and ex post trade tax ratio. The correlation between the trade/GDP and the FDI/GDP ratios is also statistically significant though less pronounced. N evertheless, openness and globalization are not the same thing. The latter refers to outcomes in terms of cross-border transactions; the former to policy inputs, whether at the border or not, that may affect globalization.

The main conclusions from Table 1 may be summarized as follows. (1) L ow-income countries as well as other groups have shared in the global growth of trade relative to national incomes of the past quarter century even though this period has seen a continuing divergence in economic growth performance; however, trade growth has not been uniform across all groups reflecting the uneven spread of the benefits of globalization and, not any less, its costs. (2) T axes on trade have declined everywhere but the relative decline is itself inversely related to income levels (trade taxes have fallen most in the high-income and least in low-income countries); in consequence, the worldwide dispersal of trade taxation has increased substantially3. (3) Countries

2 The correlation coefficients are respectively 0.69 ad 0.73 over the sample of 123 countries for 1970-96.

${ }^{3}$ This is subject to the qualification that the influence of non-tariff barriers is not captured by trade tax measures nor even entirely by measured trade outcomes. The trade tax ratio is obviously a more accurate measure of the fiscal aspect of trade taxation than of the protective aspect of trade policies. 
that had higher trade ratios and T rade Indices also tended to have higher net FDI inflows; trade openness and investment openness and/or attractiveness seem to go together; notably also, whereas low-income countries were at the low-end in terms of FDI inflows during the 1980s, the 1990s have witnessed a correction ${ }^{4}$.

T able 2 reveals trends in the main fiscal aggregates. T ax revenues as a proportion of GDP clearly rise with per capita income. In the high-income countries, this proportion is, on average, more than double that in low-income countries. N on-tax revenues are also substantially higher (5.4\%) in the upper middle-income countries than in the low-income countries (2.6\%). Lowincome countries have clearly lost tax revenue relative to GD P during the 1980s and 1990s (the fall represents $14 \%$ of the tax/GDP ratio i.e., from $15.3 \%$ in $1981-85$ to $13.1 \%$ in 1991-96). U pper middle-income countries also lost revenue to the tune of $11 \%$ in the tax/GDP ratio. By contrast lower middle-income countries lost but little between the two halves of the 1980s and then more than made up the loss to end with a higher average tax/GD P ratio during the 1990s than before. The high-income group never saw any decline in their tax/GDP ratio throughout the quarter century till 1996. Even between the 1980s and 1990s, their tax effort rose by $5 \%$.

W hat accounts for these trends in the tax/GDP ratio? The following regression estimates the relationship between the tax/GDP ratio and per capita income after controlling for size, trade taxation and the trade ratio.

${ }^{4}$ This is not to say that capital necessarily flows from the best-endowed regions nor that it flows to the worst-endowed, much less that the flows are in (inverse) proportion to existing endowments. 


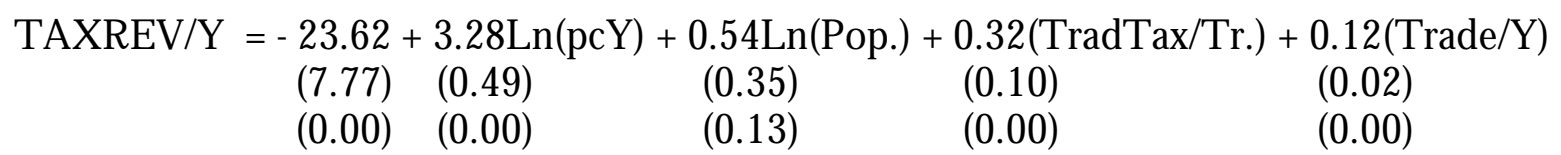

(with $\mathrm{R}^{2}=0.42$ and $\left.\mathrm{N}=217\right)^{5}$.

Per capita income raises the tax/GDP ratio from both supply and demand sides. $\mathrm{O} n$ the supply side, income growth and the accompanying structural change increases the taxable part of national income. On the demand side, income growth requires greater public investment in physical and financial infrastructure and/or increases the demand for government social services (especially social transfer programs) ${ }^{6}$.

If the above structural relationship indeed holds, then, it stands to reason that attempting to change the structure of taxation in the direction of developed country norms - the thrust of trade liberalization - particularly in a period of stagnant or falling per capita incomes cannot be achieved easily. Alternatively, such a movement may well be accompanied by increased fiscal deficits, higher foreign financing and/or reduced expenditures. For the low-income group, equation (1)

${ }^{5}$ O bservations are means of annual values for the following three periods 1970-79, 198087 and 1988-96. Here as elsewhere in this paper, the first row of figures in parentheses are standard errors and those in the second row in parentheses indicate the level of significance.

${ }^{6}$ It is noteworthy, however, that the proportion of non-tax revenues relative to total revenue is a decreasing function of per capita income. This may be accounted for by the greater involvement of LDC governments in production activities, services provision (from which some user charges are collected), monopoly trading, and the like. 
predicts a drop of $0.2 \%$ points in the tax/GD P ratio from the first half of the 1980 s to the 1990 s on account of the $8 \%$ fall in real GDP per capita and another $0.25 \%$ points on account of the drop in the trade taxes ratio relative to trade. This drop is matched, however, by the predicted rise in the tax ratio on account of the rise in the trade ratio during this period. Y et, the overall tax ratio has fallen as noted above. This suggests that revenue losses have occurred on account of significant policy and/or structural shifts that accompanied the reforms package implemented in these economies.

Total government expenditure fell steeply in all the three LDC groups between the early 1980 s and the 1990s but it rose somewhat in the high-income group of countries. For the lowincome group, total expenditure relative to GDP fell 2 percentage points, the same as the fall in current (tax and non-tax) revenues. T otal expenditure fell in the lower middle-income countries by 2.3 percentage points despite the stability of government revenues while the fall in expenditure in the upper middle-income group equaled two-thirds of the fall in government revenues. Thus, fiscal adjustment to the decline in revenues has involved varying degrees of reduction in government expenditure.

Table 2 shows that fiscal deficits averaged highest (5.2\%) in the low-income countries during the 1990s. D eficits averaged 3.3\% and 3.2\% respectively in the upper middle-income and high-income countries. The lower middle-income countries had the lowest average fiscal deficit ratio of all the groups at just $0.7 \%$. These comparisons should be viewed against the fact that aggregate fiscal expenditure and the overall fiscal take is considerably higher in the higher-income groups than in low-income countries.

All country groupings witnessed significant fiscal adjustment between the 1980s and 1990s in the form of falling average deficit ratios. B ut the low-income countries seem to have had the 
most difficulty in making the adjustment. The relative reduction in the fiscal deficit between the first half of the 1980 s and the 1990 s averaged as much as $82 \%$ for the lower middle-income countries, $33 \%$ for the upper middle-income group, $40 \%$ for the high-income group and only $21 \%$ for the low-income nations. M any developing countries were under I M F lending programs during the late 1980s and 1990s. D omestic financing of fiscal deficits has fallen while foreign financing has risen in low-income and lower middle-income countries during the 1990s.

Equation (1) suggests that the partial effect of greater globalization or openness (as measured by the trade ratio) is to raise the tax/GDP ratio. But the causal mechanisms involved cannot be presumed to be the same in developed and less developed countries. In less developed countries, with relatively high rates of trade taxation in place, a higher trade ratio increases the ability of the government to garner revenues from trade. This effect is reinforced by the fact that revenues from domestic indirect taxation are also more easily collected from trade than from many domestic sectors. Clearly, therefore, while trade increases tax revenues in LDCs, trade taxation is a requirement for this favorable linkage even though trade taxes themselves hurt trade?. The policy implication is equally clear. W hile fostering trade is one route to raising revenues, reducing trade taxation typically fails to accomplish this (see the next section), and a policy of free trade implying zero taxation of trade certainly will not. O $n$ the other hand, domestic policies and investments designed to raise the trade ratio without lowering trade taxation will help the fisc.

In developed countries, with rates of trade taxation close to zero, if a trade-fisc association holds, it cannot be due to a revenue-side effect. It has been argued that the world-wide link between

7 For the cross-country sample here, the simple correlation between the trade/GDP ratio and the trade tax ratio was 0.21 and statistically significant. 
openness and the size of government reflects the greater expenditure-side demand for public services, especially social safety nets and transfers (Rodrik, 1998). The argument above suggests, instead, a possible contrast across the world: trade and trade taxation augment the budget from the revenue side in LDCs whereas trade may increase the budget from the expenditure side in developed countries.

To examine whether this contrast holds, separate regressions were run for the developed and developing countries in the sample with government current expenditure as the dependent variable and with per capita income, population, the trade/GDP ratio and the trade-tax ratio as the independent variables. The regression for the developed country sample is:

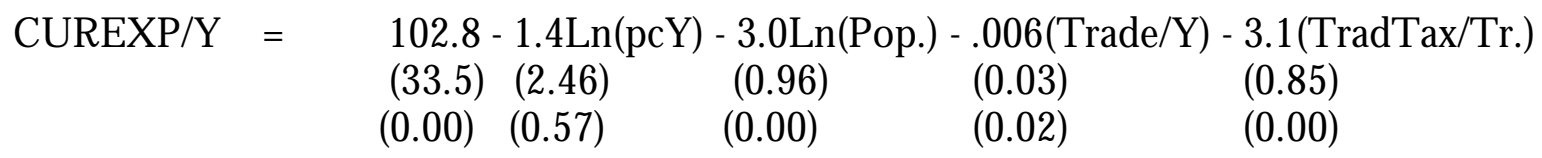

(with $\mathrm{R}^{2}=0.31$ and $\mathrm{N}=73$ )

while for the LDC sample, the regression is

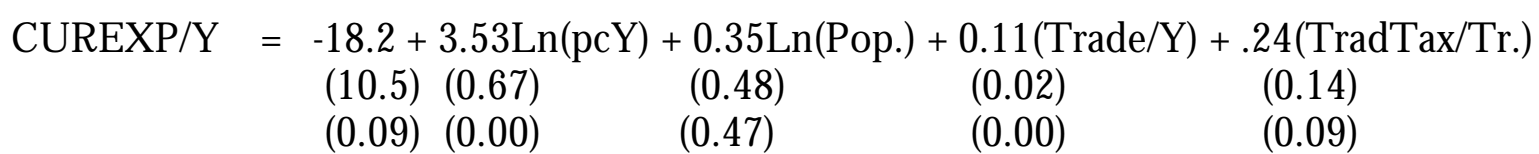

(with $\mathrm{R}^{2}=0.28$ and $\mathrm{N}=205$ ).

These results are broadly consistent with the contrast drawn above. Equation (3) shows that government expenditure in LDCs rises with the trade ratio as well as with trade taxation. By contrast, equation (2) shows that globalization and trade taxation both have negative effects on the size of public expenditure though the size of the effects is notably small. The fact that current expenditure levels actually fall with openness in developed countries throws into question the notion that openness raises the demand for social transfers. On the other hand, the positive link between globalization and public 
expenditure in LDCs may be understood as flowing from the supply- or revenue-side effect of trade taxation which serves to relieve the fiscal constraint that was described at the beginning of this section.

Apart from the structural constraints on revenue mobilization, tax revenues are also substantially more unstable in LDCs than in industrialized economies. This difference reflects the greater reliance on trade taxes which are affected by the boom-bust cycles in commodity prices and realized export revenues. Instabilities in the tax/GDP ratio are markedly greater in A frica than in any other region of the world (Zee, 1996). M oreover, in terms of instability, the largest (unfavorable) difference between LDCs and the OECD countries pertains to trade tax revenues (relative to GDP) (Zee, 1996, p. 1663). Fluctuations in export revenues affect both aggregate income and import demand both from the demand side and from foreign exchange constraints. In turn, revenues from import taxation also suffer fluctuations (Chu, 1990). Chu finds that the impact of a revenue shock in LDCs was partly met by a change in government expenditure in the same direction whereas, by contrast, revenue shocks in industrial countries lead to deficit increases that are larger than the revenue shortfalls. The difference is clearly traceable to the lack of "diverse policy instruments' ( $\mathrm{p} \mathrm{124,} \mathrm{Chu)} \mathrm{that} \mathrm{underlies} \mathrm{the} \mathrm{ubiquitous}$ public financing constraint in developing economies. The large variability in revenues means that even if a government is willing to extend its planning horizon to the medium and long terms, its ability to sustain plans is strongly limited by this form of the fiscal constraint.

\section{Tax Structure, Globalization and Revenue Effects}

Structural adjustment and policy changes oriented towards increased external integration of developing economies have entailed a significant transformation in the tax structure. This transformation 
arises not only because fiscal policies are among the main instruments for such reorientation but also because the resultant change in economic structure reacts upon the structure of public revenues. In the normal course of economic development, the fiscal structure undergoes a patterned transition reflecting the transformation in the economic structure that accompanies development. This section begins with evidence on these structural differences across countries at different stages of development. It then considers the results of globalizing policy changes of the past decade and half before focusing on changes brought on by trade liberalization in particular.

T able 3 brings out the salient differences across countries and over time in the structure of taxation. M ost obviously, the weight of direct taxation rises with per capita income levels. This becomes clearer still when we include social security taxes under the "direct taxes" rubric ${ }^{8}$ : the share of direct taxes rises from just $26.7 \%$ in the low-income countries to $39.80 \%$ in the lower middle-income, $47.2 \%$ in the upper middle-income and $60.5 \%$ in the high-income countries. But it is also noteworthy that the share of direct taxes fell in both low-income and high-income countries by about $10 \%$. It rose somewhat in the lower middle-income and significantly in the upper middleincome countries. B arring this last group, the overall trend augurs poorly for redistributive policies aimed at advancing human development. All three LDC groups also witnessed declines in social security tax collections, a similarly unpleasant development.

Less developed countries are more reliant on corporate than personal income taxes as compared to developed countries. The ratio between these two elements was around 1:3 for the OECD countries while for non-O ECD countries, the ratio was about 2:3 (Zee, 1996). At first

\footnotetext{
${ }^{8}$ This is justified because social security contributions have employment incomes and profits as
} their base. 
glance, this seems very surprising since corporate organization and corporate profits are undoubtedly a much smaller share of national income in LDCs than in developed countries. The observed inversion of shares may be attributed directly to the problems of tax administration. Thus, the very difficulty of collecting the personal tax levy in less developed countries raises their reliance on corporate taxation.

The other major development of course relates to trade tax revenue collections. T rade taxation remains far more important to the developing, especially low-income, countries than for the high-income nations. Although its share has fallen everywhere - by a fifth in the low-income group and by two-thirds in the high-income group - the change in fiscal structure this represents is far more significant in the lower two income groupings. The weight of this point is especially evident when we note that the last two decades have been a period of falling or stagnant per capita incomes in many of these developing countries. $\mathrm{H}$ ence, the move is not just the manifestation of a structural pattern characteristic of "normal" development. Rather, it is principally a reflection of the powerful tendency toward trade liberalization and other forms of policy liberalization.

In developing countries generally, much of the slack created by the decline in trade taxes has been taken up (in relative, not absolute, terms) by rising domestic indirect taxation. This is particularly the case for the low-income countries for which T able 3 suggests a law of invariance: the sum of domestic taxes and trade taxes on commodities has remained at $70 \%$ throughout the 26 year period. In many of these countries, the transition within the structure of indirect taxation from trade toward domestic taxes is also more apparent than real. Even VAT taxes are collected disproportionately from tradables (particularly importables) primarily because of the "law" of fiscal structure i.e., "tax policy is tax administration". This follows the observation that fiscal structures follow definite patterns correlated to income levels that in turn are not explained easily except by 
recourse to administrative impediments and aids in conjunction with the structure of the economy ${ }^{9}$. H ence, too much should not be made of the relative movements in the incidence of indirect taxation at the border versus within borders that is shown in the last two columns of the Table. W hile domestic indirect taxes as a proportion of the non-service GDP have moved up world-wide, this represents a real increase in rates in developing countries whereas, for the high-income countries, it is the falling share of industry in GDP (and growing tax coverage of the rising services sector) that, in all likelihood, is captured in this movement.

It is noteworthy also that high-income countries whose dependence on trade taxation has remained minuscule and falling throughout the whole period also experienced a rise in their overall tax/GDP ratios by contrast to many developing (particularly low-income) countries which suffered a decline. In other words, changes in the fiscal structure in the LDCs documented here may be considered to be "premature" inasmuch as they have entailed revenue losses exacerbating the fiscal constraint, rather than a "normal" transition.

A final point that emerges from $T$ able 3 of some significance from a policy standpoint is the observation that export taxation has fallen rather more steeply on average than import taxation. Indeed, for the low-income group, import taxes relative to imports have actually risen or remained stable between the last 3 quinquennia covered. For the other two LDC groups, however, as steep as the decline in export taxation has been, import taxation has also fallen especially over the 1990s.

The major shift in the weight of trade taxes noted above calls for closer scrutiny. Although most economists view trade taxes only in terms of their effects on resource allocation across various production activities, particularly protection for import-competing sectors, their fiscal function cannot be

9 This conclusion is also supported through cluster and principal components analyses of a wide range of countries and tax structure variables (Hitiris, 1990). 
overemphasized. As noted earlier, the positive argument for a reliance on trade taxes arises from administrative or structural imperatives in revenue mobilization. To the extent this holds, the protective effects of trade taxation may be incidental rather than fundamental to policy choice.

But even if the protective function is the primary motive of policy, fiscal feasibility may constrain the choice of policy instruments. The point may be illustrated in relation to protection of infant industries against import competition. The orthodox argument against protective tariffs has always been that they are inefficient instruments for nurturing infant industries: since the need for intervention must arise from some market failure, the proper response is to correct or compensate for that failure rather than to impose tariffs. Thus, if the failure is in the capital market, a capital subsidy should be extended. The fact that most LDCs have pursued import protection instead at least suggests the rationale that the subsidy option is fiscally costly whilst the tariff option adds to state coffers. Fiscal factors are among the most important reasons why LDC governments violate the canons of standard efficiency arguments.

As against the fiscal arguments, the principal advantages claimed for trade liberalization in LDCs include increased efficiency in resource allocation and faster productivity gains through knowledge spillovers from trade. But the size of these effects remains an object of intense controversy especially when allowance is made for the fact that a budding industrial sector, under protection, generates gains from increased division of labor and knowledge spillovers of its own. Moreover, free trade is hardly necessary for garnering the benefits promised by trade. It may, on the contrary, even be harmful by destroying an industrial base without which the benefits of trade-based knowledge and learning spillovers would be irrelevant.

Even if it be understood that trade liberalization at the margin is socially beneficial, endemic fiscal $-21-$ 
constraints subject actual policy choices in developing countries to the economics of the second-best. Inclusive of foregone opportunity costs from fiscal constriction, liberalization may not confer net benefits. Nonetheless, there is a further question that these arguments raise. If governments are dependent on trade taxes, it would seem natural to suppose that government would want to encourage trade purely for revenue reasons quite apart from any direct benefits to the economy or indirect gains to the treasury that trade expansion may bring. But it is not obvious what the means for doing so are. European states in the age of absolutism and mercantilism were inclined to 'promote' trade through the creation of trade monopolies and colonial conquest which fed their bullion store. Lacking such options, modern governments might consider fostering trade by lowering trade taxes. But this has obvious limits since the so-called Laffer curve has a positive slope below some level of the tax rate: further reductions in rates will call forth revenue declines rather than gains ${ }^{10}$. Indeed, it can be argued that although trade taxation reduces trade volumes directly and therefore confronts unpleasant Lafferian tradeoffs from a revenue standpoint, it may well be an instrument for promoting trade indirectly if the revenues obtained are used to augment infrastructure and human capital and thereby increase international competitiveness of the economy.

${ }^{10}$ Lacking precise knowledge of the trade Laffer curve, states are therefore likely to develop a schizophrenic attitude toward trade. 
The revenue effect of reduced trade liberalization is not easily predicted. Apart from uncertain Laffer effects, trade liberalization is in practice part of a package of policy moves including the relaxation and/or tariffication of quantitative trade restrictions, and real devaluation of the exchange rate. Consider the quota regime first. Unlike tariffs, quotas are not only unambiguously protective but they also do not - at least directly - contribute to the fisc. Why governments that are fiscally strapped take recourse to quotas is therefore an interesting question. One reason may be that quota rents generated in the protected sectors are more easily taxed or, where they are publicly owned, accrue to the public sector. Another has to do with their effectiveness in protection. While under certainty, tariffs and quotas have equal trade incentive effects, uncertain changes in the foreign price will alter the degree of protection afforded the local industry under a tariff whereas under a quota this is unchanged. So quotas need not be inconsistent with a fiscal constraint ${ }^{11}$. Quota liberalization, similarly, is certain whilst tariff liberalization may be neutralized by exchange rate devaluation. At any rate, the tariffication of quotas (a common element in recent liberalizations) is indeed revenue-enhancing. But once quotas have been tariffized, further liberalization must involve uncertain revenue effects.

Exchange rate policy before and after trade liberalization can make both the protective and fiscal effects of a particular liberalization package ambiguous. While a devaluation raises import values and hence import tax collections, the import tax base also erodes as import prices rise ${ }^{12}$. Prior to

${ }^{11}$ Quotas may also be a route to bestowing unearned rents on politically favored or politically powerful groups.

12 An IMF study of SAF/ESAF countries found that "a currency devaluation usually has a greater impact on raising current and capital expenditure in local currency than on raising revenue in local currency terms, which leads to a large increase in the fiscal deficit/GDP ratio" (Nashashibi et al., 
reforms, the protective effect of prevalent tariffs and quotas may be at least partly nullified by overvaluation of the exchange rate which reduces the relative price of tradables. The revenue effect of the overvaluation will be ambiguous. Conversely, a real devaluation accompanying trade `liberalization’ can exceed tariff reductions, in which case there will be an increase in the rate of protection. Again, revenue effects are ambiguous.

When adjustments are occurring concurrently in competing countries, trade liberalization and devaluation may also produce terms of trade losses. Declining terms of trade limit the tax take of governments since they reduce the tax base of readily taxed sectors. Moreover, falling commodity prices create a dilemma for governments that have price stabilization and marketing boards. They must choose between letting the fall pass through to producers which might erode the tax base and stabilizing producer prices which would reduce the tax or raise the subsidy implicit in such arrangements.

T able 4 and T able $4 \mathrm{~A}$ report the results of an exercise to decompose changes in trade tax revenues (relative to GDP) into changes in the realized rate of trade taxation (trade taxes relative to trade) and changes in the tax base (trade relative to GDP). The analysis is based on mean values of the variables for developing countries for three periods viz. 1970-79, 1980-87 and 1988-96 (respectively periods 1, 2 and 3). Changes in the mean values were converted into annualized average rates. The individual country results appear in T able 4A while T able 4 shows the averages of the country results for 4 country groupings viz. Iow-income sub-Saharan A frica (SSA), other lowincome, lower middle-income and upper middle-income. The decompositions naturally incorporate the net effects of all policy changes that countries may have undergone including

1991, p.3, ff 3). 
changes in published tax rates, changes in quota regimes, exchange rate changes. They also include terms of trade and other exogenous changes. N ote also that both export and import taxes are included in the results.

The decomposition is employed here to see whether and how far trade growth compensates for reduced protection accompanying globalization and increased economic openness. B etween periods 1 and 2, 31 of the 50 countries represented in the sample had declining average trade tax rates while between periods 2 and 3, 41 of 58 countries saw a decline, and the average rate of decline in trade taxes was $1.8 \%$ and $2.6 \%$ per year respectively. In terms both of the proportion of countries and the rate of change in trade taxation, therefore, there was a clear and cumulatively large trend of effective trade liberalization.

Table 4 shows that all LDC groups experienced revenue declines in period 3 which includes the 1990s. W hile low-income SSA and non-SSA countries saw their trade tax revenues rise in period 2 (i.e., going from period 1 to period 2), the trade tax rate was virtually unchanged in the case of the former while it rose significantly in the case of the latter. Thus, no country group in either period experienced a favorable "L affer effect" i.e., rising revenues from falling trade taxes (with the possible exception of low-income SSA in period 2). These results underline the complementary rather than competitive nature of imports and exports relative to domestic production in developing economies.

Table 4A shows that 5 out of the 50 countries in period 2 and 15 of the 58 in period 3 experienced favorable L affer effects (whether from raising or reducing trade taxation). The revenue gainers in period 3 which also reduced tax rates were G hana, India, N icaragua, Fiji, Thailand, Jordan, Paraguay, Poland, Chile and M exico. In the case of low-income sub-Saharan A frica, while $G$ hana, Zambia and Zimbabwe were the only countries that saw rising trade tax 
revenues in period 3, G hana was alone in realizing this gain from reduced trade tax rates. In period 2, trade tax revenues increased in K enya, Lesotho, M alawi, N iger, Zambia and Zimbabwe, and all of them saw increased realized trade tax rates. H ence, low-income countries in general, and SSA in particular, have been especially hard-hit by the adverse fiscal impact of trade liberalization. M ost of these economies have operated on the rising part of the realized $L$ affer curve, and therefore confront a tradeoff between reduced protection and reduced revenues from liberal reforms.

In addition to the factors already noted, changes in the structure of the economy following trade liberalization also underlie its overall fiscal impact. That is, the fiscal impact of trade liberalization is not confined to trade taxation alone but may also be felt in domestic tax collections. Two such structural changes are the expected shift in resources from import-competing to export sectors and, from capitalintensive to labor-intensive sectors. If the latter of these pairs are low-taxed sectors, then, liberalization will impose additional revenue losses. There are two reasons to expect this to be the case. First, sectors such as agriculture and small-scale export production typically escape the domestic tax net because they are legally exempt or effectively untaxed. Second, large-scale enterprises that are more easily taxed tend to be concentrated in the capital-intensive and import-competing sectors. In addition, cost pressures following trade liberalization prompt larger enterprises to sub-contract production to the small-scale and informal sectors. While these shifts may provide employment gains, there may also be revenue losses. These secondary revenue losses are likely to outweigh any revenue gains from increased allocative efficiency that orthodox theory associates with trade liberalization.

Import tariff reductions do not usually provide any concomitant reduction in government outlays. The chief reason is that government expenditures tend to be heavily concentrated on non-tradable 
goods and especially services. A secondary reason is that governments, as consumers, often do not pay import tariffs (defense is an example). On the other hand, transfer expenditures can be expected to rise in the wake of trade liberalization. Transition subsidies may have to be raised in sectors hit by import competition; retrenchment and retraining of workers organized enough to make their demands felt will add to the fiscal burden; rising food and other relative prices may have to be made good through compensatory wage increases for government employees, and through food and other subsidies to politically sensitive consumer groups.

Clearly, both the argument and the evidence underscore the fiscal squeeze, from both revenue and expenditure sides, that trade liberalization poses ${ }^{13}$. One response might be that trade taxation should be resorted to at best for protection and not for revenue reasons. Such an argument might be made on second-best grounds on the trade side and on first-best grounds on the fiscal side. Apart from the presumed optimality of the resulting policy regime, its feasibility may be secured by switching from a reliance on trade taxes to trade-neutral excise taxation or value-added taxes. Howsoever attractive this proposal may seem, its feasibility is largely a function of a country's level of development. A number of countries have introduced value added taxes (VATs) within the past decade or modified their VATs in seeking alternative revenue sources. However, the revenue results have often been mixed. Countries that had the lowest initial levels of tax revenue relative to GDP also fared the worst in terms of successfully introducing the VAT or other reforms in fiscal structure as well as in generating additional revenues. This holds the important lesson that "programs designed to raise revenue over time in low-

${ }^{13}$ The fiscal impact of trade liberalization documented in this paper illustrates the "double jeopardy" to public finance that globalization threatens (Grunberg, 1998). 
income countries should take account of administrative constraints" (Abed et al., 1998, p.4). Efficient and effective revenue mobilization may be more important in these countries than aiming for fiscal reforms toward a textbook ideal of minimizing allocative inefficiency. In many countries, moreover, even the VAT is not 'trade-neutral' in the sense that a greater part of the tradable sectors is subject to the VAT than of domestic non-tradables so that the efficiency rationale for the shift is blunted.

Another policy argument is that the fiscal squeeze is only a short-run or transitional problem that will remedy itself once the economy settles into a new steady state with liberalized trade. However, the promise of income gains in the long run must be viewed with caution if major distortions remain in the rest of the economy ${ }^{14}$. With widespread infrastructure and human capital constraints typical of poor countries, constraints that are closely related to the fiscal constraint, the long run gains (if they do exist) may prove unrealizable since the transition entails a worsening fisc and this could lock the economy into a bad but politically self-sustaining equilibrium. In the presence of such distortions, a liberalization may even end up reducing income and welfare.

Under the circumstances, the success of trade "liberalization" is to be judged not by how close to free trade a country gets but rather by how well it mediates between the endemic fiscal and foreign exchange constraints of developing countries. At the margin, a relaxation of the exchange constraint would give a potentially strong boost to investment provided that the means by which the relaxation is effected do not worsen government finances. The qualification is necessary because a relaxation of the fiscal constraint too would provide an investment spur. Trade liberalization can be useful in this sense

${ }^{14}$ Following the theorem of the second best, given major distortions elsewhere in the economy, a liberalization may end up reducing income and welfare. 
but, for the reasons and evidence given above, only within fairly narrow limits. Beyond this, no persistent net growth contribution should be expected for such a potential remains in the realm of speculation.

\section{Financial Liberalization and the Fiscal Squeeze}

Apart from trade liberalization, liberalization of the external account and of the domestic financial system have been at the core of attempts at globalization. The liberal presumption has been that barriers to financial mobility across borders are essentially policy-induced and that these are costly. A relatively closed financial system has or entails controls on interest rates, exchange rates and the capital account, and the regulation of credit allocation - in short, financial 'repression' that produces inefficiencies in both portfolio holdings and in investment allocation. Internal liberalization stimulates domestic saving and improves its allocation via financial markets. External integration permits global market forces to determine interest rates, bond and equity prices and the foreign exchange rate.

Although global financial flows have increased sharply in the 1990s, both foreign direct investment and portfolio flows seem to follow development rather than lead it. Long-term global financing of investment still remains a small share as revealed by the persistent and high correlation between national saving and investment rates. International interest rate differentials also remain stubbornly high (Avramovic, 1993). And much of that long-term flow is heavily concentrated in a dozen or so countries. Yet, the potential returns not merely to physical capital investments but also to human capital and infrastructure investments in LDCs are undoubtedly high. It is evident therefore that global financial markets and flows are deeply fragmented rather than integrated. 
While it might be argued that this anomaly arises from the pursuit of improper macroeconomic policies and government controls of the financial system, such an assessment ignores, on the one hand, the underlying structural constraints and market failures and, on the other, the limited scope for liberal policy choices without imposing potentially costly tradeoffs including exacerbation of fiscal constraints. Indeed, fragmentation characterizes even the domestic financial markets in LDCs. Finance flows but unevenly among the modern industrial sector where much of the learning process must concentrate, the informal and agricultural sectors which are the prime sources of employment and livelihoods, and the public sector which must play the leading role in creating infrastructural and human capital. Uneven access to finance and wide differences in interest rates arise essentially from financial market failures owing to significant externalities and information asymmetries, and from the finance-fisc nexus (see below). In other words, intra-national fragmentation of finance is not unlike the global fragmentation noted above. Moreover, different parts of indigenous financial markets, even when not closed by policy, are highly unevenly connected with global markets.

The fiscal constraint and the uneven development of finance interact strongly to limit policy choices. The fiscal constraint, particularly the dynamic lag in relation to growth, implies that the public sector financing requirement runs well ahead of government revenues and borrowing capacities. Governments have resorted to forced finance: by monetizing the deficit and forcing saving via inflation or by requiring domestic banks, through reserve and portfolio requirements, to accommodate government finance. Forced saving and financial repression both have their economic and political limits but so does revenue mobilization. Prudential regulation apart, a major reason for controls over banking in LDCs arises from the fiscal constraint. But note also that such controls cannot be sustained without a captive 
supply which, in turn, is a prime motive for external capital controls. Thus, financial repression together with capital controls may be understood as arising, in major part, from financial market fragmentation and the infeasibility of first-best policies for public financing.

Hence, it is to be expected that attempts at liberalizing and opening up the financial system are liable to impose fiscal costs. One source of this cost arises from relaxing financial repression It has been estimated that the implicit fiscal gain from repression amounted to $2 \%$ of GDP (Giovannini and de Melo, 1993). Similarly, reduced monetization of the fiscal deficit that is compelled by financial liberalization results in the loss of seignorage revenues; as inflation declines, the inflation tax also falls as governments cannot reduce their debt obligations through a declining real value of money. Thus, in LDCs with large fiscal deficits, while the loss in real value of government liabilities held by the private sector averaged $2.7 \%$ of GDP in 1983-89, it fell to $1.7 \%$ of GDP in 1990-95. The corresponding figures for countries with moderate fiscal deficits were $3.5 \%$ and $2.8 \%$ respectively (IMF, 1996).

Exchange rate changes matter not only for the external balance but also for the fiscal balance. Devaluations raise debt service burdens directly that rest disproportionately on the budget while benefiting the private export sectors which may not be easily taxed. It should also be noted that there are secondary fiscal impacts flowing from losses in trade tax and other sources of revenue noted in the previous sections. Revenue losses induce a rise in the domestic and/or foreign debt which may force up the interest rate and thus the interest burden on the budget.

Table 5 draws attention to contrasting trends across country groups in public debt and the burden of servicing that debt. W hereas the debt/GD P ratio has, between the early 1980s and the 1990s, remained essentially stable in the high-income and lower middle-income groups (at about 
$50 \%$ ), it has doubled from about $50 \%$ in the low-income group. Even the upper middle-income group has stabilized its debt/GDP ratio over the last decade after an initial rise. The trend in the public interest burden follows these trends rather closely. In particular, interest expenditure relative to GDP in low-income countries has risen sharply from $1.5 \%$ to $3.6 \%$ in the space of a decade. W hile the interest burden in low-income countries is not much above that in the lower middle-income group (and is in fact lower than in the other two groups) when measured relative to GDP, it represents a much greater and growing fiscal constriction given their much lower tax/GDP ratio which has also been falling in this period. Thus, as a share of total current expenditure, the interest burden has risen from $6.1 \%$ in the early 1980 s to $15.5 \%$ in the 1990 s.

The period of adjustment represented in T able 5 has not seen any rise, rather some decline, in the ratio of gross domestic investment to GDP. There has been a noticeable trend toward privatization in investment (witness the rise in the private sector proportion of gross domestic fixed investment) everywhere, especially in the middle-income groups. At least in terms of raising the realized domestic investment ratio, the trend toward privatization and greater reliance on foreign investment has not helped.

A revealing if crude index capturing the fiscal impact of trade and financial liberalization is provided by changes in government interest expenditure and trade tax revenues (both relative to GDP). First, define a fiscal index by the difference between trade taxes and interest expenditures:

$$
\text { F-INDX } \quad=\quad(\operatorname{TradTax} / Y)-(\operatorname{IntExp} / Y)
$$

B etween-period reductions in this index may be taken to represent the degree of fiscal "squeeze" related to trade and financial liberalization. Thus,

$$
\text { F-SQZ }=\quad \ddot{A}(\operatorname{TradT} \mathrm{ax} / Y) \quad-\quad \ddot{\mathrm{A}}(\operatorname{IntExp} / Y)
$$

Tables 6 and 6 A show the results for a cross-section of LDCs. As before, the time periods for 
which the fiscal squeeze index and its components are calculated are 1970-79, 1980-87 and 19881996 (periods 1, 2 and 3 respectively). Based on underlying level variables that are averages for the respective periods, between-period changes are computed as changes in those averages between successive periods. Accordingly, change indicators pertain to periods 2 and 3.

The first three columns of T able 6 summarize the fiscal squeeze variables for the 4 LDC country groups (low-income SSA, other low-income, lower middle-income and upper middleincome) while the corresponding columns in Table $6 \mathrm{~A}$ show individual country results. A negative value for the fiscal squeeze variable indicates an adverse fiscal impact. For virtually all country groups and both time periods, T able 6 shows both revenue losses on the trade account and expenditure rises on the interest account. The rise in interest expenditure was the dominant contributory factor except for low-income SSA and lower-middle-income countries in period 3 when losses from trade taxation constituted a sizable share of the fiscal squeeze. The fiscal squeeze ranged between 1 and 2 per cent of GDP in both periods. Between the two periods, the index rose in both the low-income groups, fell in the lower middle-income group and stayed unchanged in the upper middle-income group. Table 6A shows that 46 out of 58 countries in period 2 and 45 of 61 countries in period 2 experienced a fiscal squeeze.

W hile the fiscal squeeze index is only an accounting device, the following regression shows that it is closely related to both trade liberalization and the financial consequences of opening up after controlling for changes in the trade/GDP ratio ${ }^{15}$.

15 The fiscal squeeze index is entered with a negative sign in the regression. 


$$
\begin{aligned}
& - \text { FISSQZ }=0.46-0.07 \ddot{A}(T \operatorname{radT} \text { ax/T r. })+0.17 \ddot{A}(I n t E x p / C u r E x p)-0.17 \ddot{A}(T \mathrm{rad} / \mathrm{Y}) \\
& \text { (0.23) (0.02) }
\end{aligned}
$$

(with $\mathrm{R}^{2}=0.26$ and $\mathrm{N}=163$ ).

Trade liberalization is here indexed by changes in the ratio of trade tax revenues to the value of trade whilst financial policy changes are captured by changes in the ratio of government interest expenditure to total current expenditure. Both variables have the expected signs and are statistically significant. The regression also shows that countries that improved their trade shares of GDP reduced the fiscal squeeze.

\section{Infrastructure and Human Development Impacts}

The adverse fiscal effects of liberalization and globalization have implications for both economic development and income distribution. These flow directly from the fiscal squeeze that can reduce both infrastructure and human development expenditures on the public account. There are also important indirect effects to be considered. One such effect arises from the greater amplitude of fluctuations in incomes and relative prices, not to mention financial crises of the sort seen recently in Asia, Russia and elsewhere, that globalization brings in its train. These are apt to hurt especially the poor and vulnerable segments of the population. Another indirect effect flows from income redistributions due to reductions in real wages, increased informalization, and increased skilled/unskilled wage differentials. Real income reductions of the poor may also be induced by increased relative prices of food, cuts in food and other wage goods subsidies, higher user charges for health and educational services, etc.

Low-income countries with low levels of human development seem particularly to be in danger 
of marginalization due to globalization. One reason is that these countries are especially hard hit by the fiscal impact discussed in the preceding sections. Second, with low levels of human development, they lack the capabilities to benefit from globalization. Human development and good infrastructure are key to both industrialization and raising international competitiveness. Third, lacking established safety nets, they are liable to experience the backwash effects of globalization such as de-industrialization, terms of trade losses, and trade-induced instability.

Raising the level of human development is principally a matter of raising investment, especially public investment, and of reaching large sections of the population that the market bypasses. Both factors originate from pronounced externalities in such areas as health, education, and training, and market failures in insurance, credit, and infrastructure creation. On the face of it, the required investments and provision of opportunity should have nothing to do with a policy of globalization i.e., they have to be undertaken as part of any program of economic development quite independently of policies with respect to external integration. But this is simply not so. While low levels of human development and infrastructure make poor countries more vulnerable to the costs of globalization without being able to benefit from it, globalization also makes it more difficult for them to raise their levels of human development and infrastructure. This suggests a cumulative process that can hold back development. Clearly, the government budget is a crucial link in this process.

T ables 6 and $6 \mathrm{~A}$ provide cross-country evidence on changes in government expenditure on the capital account and on education as well as changes in gross domestic investment (all relative to GDP). As the T ables show, time-series data on government education expenditures are less abundant than for capital expenditure. Although ideally health expenditures and other human 
development expenditures should also be considered, adequate cross-country time-series were unavailable. The group-wise averages in T able 6 show that government capital expenditure fell in all the four groups in period 3 which includes the 1990s. Note also that low-income SSA suffered a decline in education expenditures in the latest period.

On the other hand, gross domestic investment recovered in low-income SSA after a decade of decline accompanied by declining per capita incomes but this recovery was marginal at best, a bit above neutralizing the earlier decline. The other low-income group experienced rising investment but investment growth slowed down substantially between the two periods. By contrast, middle-income countries witnessed a continuation of falling investment ratios with only a small drop in the rate of decline.

The declines in government capital expenditure and gross domestic investment are related to each other but more importantly, these declines took place in a period when the fiscal squeeze from globalization was also taking effect. As we argue below, the trend in public educational expenditures is also related to the fiscal squeeze though this may not be immediately apparent. The following regression reveals the link between the fiscal index (defined in equation 4) and public capital expenditure controlling for income, size and the trade ratio.

$$
\begin{aligned}
& \text { PUBINV/Y }=5.46-0.58 \mathrm{Ln}(\mathrm{pcY})+0.06 \mathrm{Ln}(\mathrm{Pop} .)+0.04(\mathrm{Trade} / \mathrm{Y})+0.25(\mathrm{~F}-\mathrm{INDX}) \\
& \begin{array}{lll}
(5.07) \quad(0.32) & (0.24)
\end{array} \\
& (0.28) \quad(0.07) \quad(0.81)
\end{aligned}
$$

(with $\mathrm{R}^{2}=0.26$ and $\mathrm{N}=196$ ).

This result supports several interesting conclusions. First, public investment is inversely related to per capita income levels. This shows that infrastructure and related capital expenditure requirements are larger in countries at the beginning stages of modern economic growth and/or that a greater part of 
such capital expenditures tend to be publicly organized and financed in such countries. Either way, this indicates the greater importance of the public finance constraint in countries at low levels of development. Second, this last conclusion is directly confirmed by the positive and statistically significant coefficient for the fiscal index. Countries that were fiscally squeezed by lowered trade tax revenues and/or increased interest expenditures tended to have a lower rate of public capital expenditure. Capital expenditure falls by one quarter of any drop in the fiscal index. Finally, the positive coefficient on trade shows that, all else being the same, enlarged trade increases public capital expenditure. Since the tax-base effect of trade on public revenues is already captured by F-INDX, this coefficeint probably reflects a foreign exchange constraint: higher trade volumes indicate a relaxation of that constraint which serves to push up public investment.

The above specification was repeated using the total of public capital and public education expenditures as the dependent variable and the following result obtained:

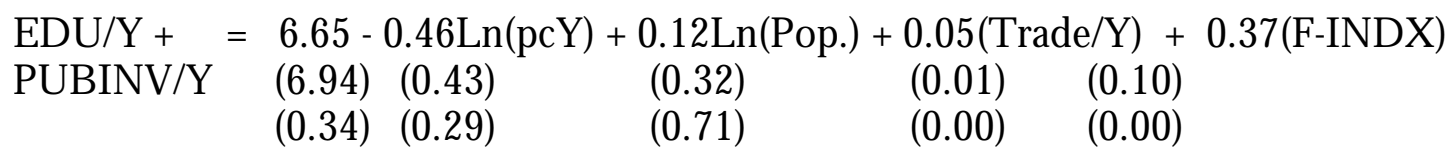

(with $\mathrm{R}^{2}=0.387$ and $\mathrm{N}=127$ ).

Note that the income coefficient is not statistically significant although it remains negative as in equation (7). The smaller size of the sample than for equation (7) may be a factor here. At any rate, equation (8) reveals a large and significant coefficient for the fiscal constraint as indexed here. With a $\$ 1$ decline in trade-tax revenues or rise in government interest expenditure, public expenditure on capital formation and human capital falls by $\$ 0.37$. This result is consistent with the one obtained in equation (7) for public capital formation alone. 
As the key determinant of economic growth, it is of considerable interest to see how gross domestic investment reacts to the fiscal index. Apart from income per capita and size, the specification below controls for the trade ratio, public capital expenditure and educational expenditure.

$$
\begin{aligned}
& \mathrm{GDI} / \mathrm{Y}=-61.74+2.75 \mathrm{Ln}(\mathrm{pcY})+3.24 \mathrm{Ln}(\mathrm{Pop} .)+0.08(\text { T rade } / Y)+0.69(\mathrm{~F}-\mathrm{INDX}) \\
& \begin{array}{llll}
(9.29) & (0.59) & (0.42) & (0.02)
\end{array} \\
& \begin{array}{llll}
(0.00) & (0.00) & (0.00) & (0.00)
\end{array} \\
& +0.67(\mathrm{CapE} \times \mathrm{xp} / \mathrm{Y})+0.72(\mathrm{E} d u c E x p / Y) \\
& (0.14) \quad(0.30) \\
& (0.00) \quad(0.02)
\end{aligned}
$$

(with $\mathrm{R}^{2}=0.49$ and $\mathrm{N}=132$ ).

All variables bear the right sign and are statistically significant. The investment ratio is an increasing function of both per capita income and population size. Following the previous interpretation, the positive coefficient on the trade ratio indicates a foreign exchange constraint on accumulation. As for the fiscal constraint, a $\$ 1$ loss of revenue from trade or increase in the interest burden leads to a decline of \$0.69 in gross domestic investment. Again, this result provides further confirmation of the fiscal fetter on accumulation. Two further conclusions may be noted. Educational expenditure has a large and positive impact on domestic capital formation. Thus, public investment in education and total investment in physical capital are strong complements. Finally, the coefficient on public capital expenditure though positive is less than unity. While this seems to indicate a crowding-out of private investment, this result should be seen together with the large positive coefficient on F-INDX. Thus, enhanced fiscal capacity would seem to have a strong direct effect of crowding in private investment as well.

The above results regarding the determinants of public investment expenditure, public educational expenditure, and domestic capital formation, underline the centrality of the fiscal constraint 
for economic growth and human development. Together with the results in preceding sections showing significant adverse fiscal effects from globalization, this refutes the notion that human development need have nothing to do with a policy of globalization. Rather, it indicates an important tradeoff between external integration and internal integration with the government budget providing the fulcrum of that tradeoff. Liberalization shifts resources from the public to the private sectors thus exacerbating the budget constraint. This not only lowers public investment but, in the end, also serves to lower economy-wide accumulation.

While externally-oriented liberalization has been promoted mainly with a view to the efficiency gains it is promised to deliver, its distributional effects may in fact be more important in both political and economic terms. One such effect is the redistribution from government to the private economy which we have just considered. The other of course pertains to redistributions within the private sector. Such redistributions arise from relative price changes and the consequent resource reallocations and factor price changes. Attempts at liberalizing domestic economies and integrating with world markets impose costs on some groups while benefiting others; hence they pose political problems which may show up in the budget.

Yet, these demands on the budget that globalization produces pile up on top of reduced revenues and increased debt obligations. The paradox of globalization is that it places the strongest demands on the weakest states after weakening them further. This is related to two considerations. On the one hand, the fiscal losses from globalization are largest for the poor countries. On the other, it is the poor countries that have small and fiscally weak states to begin with; the developed economies have large governments whose capabilities have been built up in the course of development. As Tanzi (1998) 
has pointed out, "The reason is not that the [advanced industrial countries] need more government than the [poor countries] but because they can collect more taxes" (emphasis added). Yet, it is the poorer countries that need fiscally stronger states to cope with widespread market failures and complex distributional changes.

Relative price shifts that accompany globalization may also weaken the fisc. Liberalizing agricultural prices, for example, can produce large real transfers from poor consumers (for whom food is the overwhelming part of private expenditure) to agricultural rentiers and traders ${ }^{16}$. When developing countries as a group face pressures to get their agricultural-exportable prices "right" i.e., alignment with world price levels, this will also produce a net transfer of resources to the consuming countries via terms of trade losses. These effects are additional to the permanent increase in the variability of producer prices and export earnings that openness entails, and to the transitory costs of de-industrialization and unemployment that adjustment requires.

The real income loss of poor food consumers due to liberalized food and agricultural prices will be reinforced if food or fertilizer subsidies are cut at the same time. In such cases, the redistribution does not implicate the fisc directly. But note that indirect effects on the budget are likely e.g., if government employees demand and secure compensatory nominal wage increases, government current

16 Higher agricultural prices will also lower the real wage of labor to the extent that agricultural (food and raw material) goods figure heavily in labor's consumption bundle even though agriculture is labor-intensive. 'Peasants', on the other hand, gain as owners of land but may lose as food consumers or labor suppliers. 
expenditure will rise or, if private non-agricultural employees are similarly compensated, government tax revenues decline along with non-agricultural profits. But political compulsion might force the government also to extend or at least maintain food subsidies. The rise in food prices, however, entails a larger fiscal outlay for such subsidies to achieve the same real subsidy level. The budget rarely goes unscathed from major price realignments as in the present example.

In standard trade theory, when trade arises from factor endowment differences rather than intraindustry competition, trade liberalization will reduce the income of the scarce factor while benefiting the abundant factor of production. A great deal of trade between rich countries and developing countries is probably largely complementary in this sense (with specialization predicted by comparative advantage). The usual presumption in a two-factor world is that abundant labor will gain at the expense of scarce capital in LDCs. There are a number of qualifications however. First, with large reservoirs of underemployed or surplus labor, the relative price shifts from trade opening will produce employment rather than wage increases. Second, trade opening can be expected to reduce employment and wages in import-competing sectors, and as firms seek to reduce costs, lower workplace standards and weaken trade unions, minimum wage enforcement, etc. Third, with a third factor present in the form of skilled labor, a rise in unskilled wages is no longer assured. If skilled and unskilled labor are easily substituted, then, the skilled-unskilled wage differential may widen and wage-based inequality rise. This last effect may be reinforced if technical change favoring substitution of skilled-labor and capital for unskilled labor accompanies liberalization. Similarly, with agricultural land as the third factor, a real wage increase from liberalization is not assured.

For developing countries, evidence on changes in absolute poverty and relative inequality (both $-41-$ 
in terms of the personal distribution of income) are rather more available than evidence on the functional distribution of income which the foregoing arguments relate. Of course, the two distributions are closely related in general. Accordingly, cross-country evidence over the period 1970-95 has been examined to see if there are broad associations between trends in openness on the one hand and poverty and inequality on the other (Rao, 1998). Openness is measured by the export/GDP ratio and the Trade Index (which is the trade/GDP ratio after eliminating the effects of per capita income level and population size). The majority of countries in the sample witnessed a rise in their openness. There were a number of countries in which poverty, as measured by the head-count ratio below US \$1 per day, increased though the numerical edge was on the side of those where poverty decreased. The sample as a whole shows a positive (and statistically significant) relationship between changes in the Trade Index measure of openness and changes in poverty with an adjusted $R^{2}$ of $0.29^{17}$. Countries with declining poverty had on average an openness trend of $0.1 \%$ per annum whilst those with rising poverty had an average openness trend of $2.1 \%$ (the corresponding figures for the export/GDP index of globalization were $0.7 \%$ and $2.0 \%$ pa).

17 There was, however, no statistically significant link between poverty changes and trends in the export/GDP measure of openness. 
Turning to the link between changes in openness and inequality, few countries in the sample witnessed a decline in both openness and inequality. Observations showing a rise in inequality were rather evenly divided among those with rising openness and falling openness. Countries opening up similarly showed roughly equal proclivity to become less unequal as more unequal. Although there was a positive relationship between the trend in openness (Trade Index) and the trend in inequality, the regression coefficient was not statistically significant at any conventional level ${ }^{18}$. In terms of sample means, countries with declining inequality had an openness trend of $0.6 \%$ pa while those with rising inequality opened up at $1.1 \%$ pa (the corresponding figures for trends in the export ratio or globalization are $2.0 \%$ and $1.6 \% \mathrm{pa})$.

From a policy standpoint, dealing with the poverty, dislocation, volatility and distributive effects of globalization may be considered in terms of tax and expenditure policies. Consider the tax policy potential. Ideally, taxes must be designed so as to strengthen the fisc and promote human development, objectives that would seem best served by a progressive structure of taxes. As already seen, this need not have a net disincentive effect on domestic investment; on the contrary, such a structure would be complementary to economic growth.

But administrative (and political constraints) related mainly to low levels of development remain formidable barriers. Tangible wealth and property which constitute the real base of taxable incomes have been particularly difficult to tax in poor countries whereas human capital which constitutes the larger taxable element in rich countries is more easily taxed in the rich countries. Though much is made

18 Similarly, the export measure of globalization explained little of the variation in inequality. 
of the influence of tax rates on tax compliance, lax enforcement allows ample scope for evasion of both direct and indirect taxes whatever the rates. Most taxable incomes in the informal sectors simply escape the tax net, agricultural incomes and wealth are typically exempt from taxes, and corporations and the well-to-do in the formal sector get away with legal concessions and artful subterfuge. Official corruption imposes its own tax on the state's rightful take. Similarly, public services though formally offered free are often subject to informal charges. A major problem that arises from the heterogeneity of enterprise structures in developing countries is that of horizontal inequity: the unequal treatment of equals. Thus, small entrepreneurs escape taxes which the salaried classes with similar incomes must cough up. In turn, of course, this inequity affects the economic structure and enlarges the range and scope of activities where tax evasion is less costly. Yet, global integration tends to shift the tax structure further in a regressive direction. Thus, regressive shifts from corporate and personal income taxes, and trade taxes, towards consumption-based taxes like VAT are increasingly accepted as inevitable or, result from competitive concessions. One of the ironies of globalizing liberalization is that administratively insecure tax bases are increased at the expense of secure tax bases.

Expenditures on social safety nets take diverse forms across countries but in developing countries as a rule, free access to health and education, subsidies for items consumed by the poor, especially food, and crises or temporary measures for those in distress, constitute the chief forms. Pensions, health insurance and unemployment benefits, programs characteristic of advanced economies, are virtually non-existent ${ }^{19}$. T able 7 puts together readily available data on public expenditures on

19 W hile many relatively high-income east $A$ sian economies have relatively low tax-GD P ratios (Zee, 1996), this seems due, considering their levels of income, in major part to their lack of 
health and education, and also public capital expenditures. D ata of adequate quality are sparse both in country and time-period coverage. It is notable that the GDP share of government capital expenditure in low-income countries is considerable higher than in rich countries (6.1\% in 1991-96 compared to $2.5 \%$ ). This gap is higher still when capital expenditure is reckoned relative to current expenditure (27.1\% for low-income countries in the 1990 s compared to only $6.7 \%$ for highincome countries). After falling in the 1980s, education expenditures relative to GDP in lowincome countries have recovered lost ground in the 1990s. On the other hand, health expenditures have fallen (from 1.8\% of GDP in the late 1980s to 1.6\% in the 1990s). B oth health and education public expenditures have stagnated or fallen in the middle-income groups.

Combating poverty, whether endemic or transitional, with pure cash tax-and-transfer programs is not administratively practicable and subject to even greater leakage to unintended beneficiaries than the conventional in-kind transfers. Yet, there are strong advocates of cost recovery even from the slender safety nets that in-kind transfers represent in poor countries. User charges, not to mention private alternatives, are advocated even in the areas of urban hospitals, clinics, universities, and transport. The assumption is that secondary and tertiary education as well as most curative care are private goods which will find private alternatives if government did not commit to footing the bill. The implication is that greater social security can be achieved at lower costs by relying on communities and households to take up the slack. The principle that user charges be confined to curative care and for tertiary education while primary care and education be supplied free seems sensible enough. But there

significant government-mandated safety nets. In the past, this seemed defensible given labormarket institutions and norms that limited the unemployment-generating impact of business fluctuations. But this is now changing as the norms are tested by the deep financial crises of the recent past. 
are overwhelming administrative problems in maintaining user charges, policing informal charges, and confining subsidies to the deserving poor ${ }^{20}$.

Infrastructure expenditures fulfill a vital allocative function of governments in LDCs primarily because of the presence of large market failures and externalities. They are also arguably the most important or at least most accessible instruments by which the benefits of development can be diffused across the population. But unless these expenditures are financed mainly through taxation, the resulting fiscal deficits are likely to work against equitable outcomes.

\section{Conclusion}

This paper has been concerned primarily with the fiscal consequences of various measures of policy liberalization designed to increase the global integration of developing countries. Its principal conclusions are that globalization has further accentuated the fiscal constraints facing states, and that there is a cumulative process of causation between liberal policies and the fiscal constraint. These conclusions imply that the fiscal basis of constructive state action to promote human development and resolve distributive conflict is now more limited than before.

${ }^{20}$ Improved targeting of subsidies to maximize budgetary savings ignores ground realities. For example, generalized commodity subsidies, it is believed, should be replaced with subsidies or cash transfers that are narrowly targeted to the "truly needy" (see Chu and Gupta, 1998, p.91). In many cases, just the opposite recommendation seems to be called for from the viewpoint of meeting both administrative constraints and fiscal sustainability. 
But globalization is not just an autonomous development, resulting from technological imperatives; it is also driven by policy choices. Liberalization has been the principal policy instrument of globalization in trade and finance. Thus, not only international financial institutions but also states as policy-makers, have played an essential determining role in this process of external integration. Hence, it appears as something of a paradox that states are seen as helpless in the face of the forces of globalization. The paradox dissolves once it is recognized that the global arena of policy has both powerful and weak players, countries able to take advantage of the global marketplace and those vulnerable to its compulsions, individual countries and various collectivities of nations, active agents of change and passive onlookers. The fiscal autonomy of states has been trimmed, in part, by states acting autonomously and powerfully.

Even if there are significant long-run benefits to globalization (this remains a controversial claim), the transition to greater global integration in developing countries requires strong public action and a stable fiscal base. The push to globalization can and has been premature from this viewpoint. Globalization and human development are not orthogonal to each other. There are significant tradeoffs between them mediated especially through the fisc. Developing country governments are especially constrained by the paucity of tax and expenditure instruments which conflicts with accepted canons of economic efficiency and 'good' macroeconomic policy which globalizaton is supposed to enforce. States must retain the autonomy from global market forces necessary to pursue nationally and politically determined tradeoffs. 


\section{REFERENCES}

Abed, George T. et al. 1998. Fiscal Reforms in Low-Income Countries. Washington DC: International Monetary Fund.

Avramovic, Dragoslav (1992). Developing Countries in the International Economic System: Their Problem and Prospects in the Markets for Finance, Commodities, Manufactures and Services. New York: United Nations Development Program. Human Development Report Occasional Papers No. 3.

Chu, Ke-young. 1990. "Commodity Exports and Public Finances in Developing Countries.” in V. Tanzi. Fiscal Policy in Open Developing Economies. Washington, DC: International Monetary Fund.

Chu, Ke-young and Gupta, Sanjeev. 1998. Social Safety Nets: Issues and Recent Experiences. Washington DC: International Monetary Fund.

Giovannini, A. and de Melo, M. 1993. "Government Revenue from Fiscal Repression.” American Economic Review. 83:953-963.

Grunberg, Isabelle. 1998. "Double Jeopardy: Globalization, Liberalization and the Fiscal Squeeze." World Development. 26:591-606.

Hitiris, Theo. 1990. "Tax Structure, Trade Taxes, and Economic Development: An Empirical Investigation." in V. Tanzi. Fiscal Policy in Open Developing Economies. Washington, DC: International Monetary Fund..

International Monetary Fund. 1996. World Economic Outlook. Washington DC: International Monetary Fund.

Nashashibi, K., Gupta, S., Liuksila, C., Lorie, H. and Mahler, W. 1991. The Fiscal Dimensions of Adjustment in Low-Income Countries. Washington, DC: International Monetary Fund.

Rao, J. M ohan. 1998. O penness, Poverty and I nequality. Background paper for the H uman D evelopment Report 1999, N ew Y ork: UNDP.

Rodrik, Dani, 1998, Has International Integration Gone Too Far? Princeton Univeristy Press.

T anzi, Vito. 1998. "Fundamental D eterminants of I nequality and the Role of G overnment." W ashington, DC: International M onetary Fund. 
Zee, H owell. 1996. "Cross-country T ax Revenue Comparisons." W orld D evelopment. 10:165971. 
TABLE 1: Trends in Economic Openness

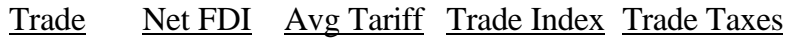
(\% of GDP) (\% of GDI) (\% of Trade)

(\%) (\% of Trade)

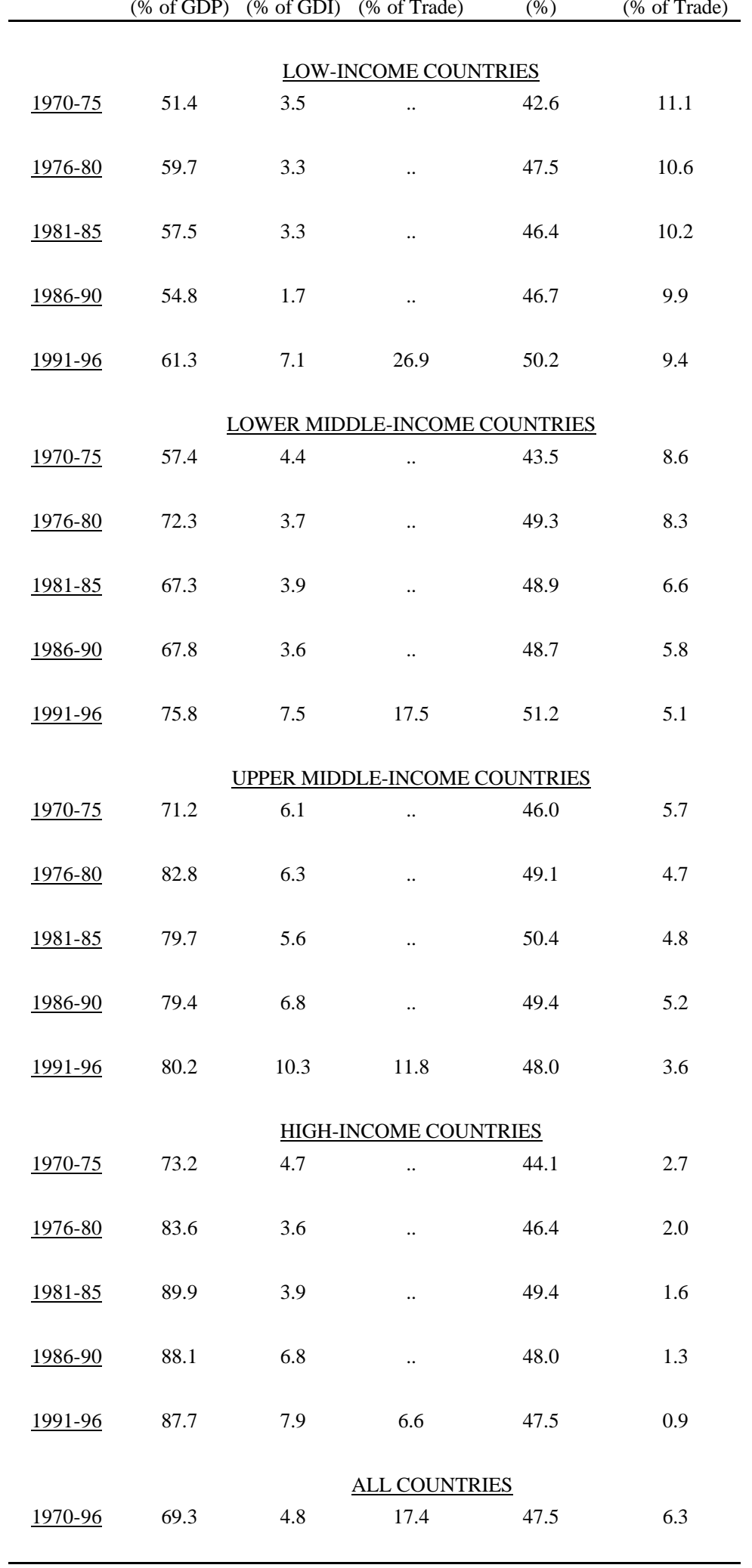


TABLE 2: Trends in Fiscal Aggregates

$\underline{\underline{\text { Nontax Rev }}} \underline{\text { Tax Rev }}$ Cur Rev $\underline{\text { Tot Exp }}$ Fis Bal $\quad \underline{\text { For Fin }}$ (\% of Gross Domestic Product) (\% of GDP) (\% of Fis Bal)

\begin{tabular}{|c|c|c|c|c|c|c|}
\hline \multirow[b]{2}{*}{$\underline{1970-75}$} & \multirow[b]{2}{*}{2.0} & \multicolumn{5}{|c|}{ LOW-INCOME COUNTRIES } \\
\hline & & 13.6 & 15.6 & 18.9 & -3.5 & 56.1 \\
\hline$\underline{1976-80}$ & 2.2 & 14.1 & 16.3 & 22.0 & -5.5 & 47.5 \\
\hline 1981-85 & 2.3 & 15.3 & 17.7 & 24.5 & -6.6 & 45.0 \\
\hline$\underline{1986-90}$ & 2.6 & 13.9 & 16.6 & 24.7 & -6.3 & 42.5 \\
\hline \multirow[t]{2}{*}{$\underline{1991-96}$} & 2.6 & 13.1 & 15.7 & 22.5 & -5.2 & 53.9 \\
\hline & & \multicolumn{5}{|c|}{ LOWER MIDDLE-INCOME COUNTRIES } \\
\hline$\underline{1970-75}$ & 3.8 & 14.8 & 18.7 & 20.9 & -2.4 & 80.1 \\
\hline$\underline{1976-80}$ & 4.9 & 16.2 & 21.2 & 26.0 & -4.4 & 54.3 \\
\hline 1981-85 & 5.0 & 17.1 & 22.1 & 26.0 & -3.9 & 50.8 \\
\hline$\underline{1986-90}$ & 5.3 & 16.6 & 22.0 & 23.6 & -1.3 & 38.1 \\
\hline \multirow[t]{2}{*}{$\underline{1991-96}$} & 4.5 & 17.8 & 22.3 & 23.6 & -0.7 & 55.1 \\
\hline & & \multicolumn{5}{|c|}{ UPPER MIDDLE-INCOME COUNTRIES } \\
\hline$\underline{1970-75}$ & 6.7 & 19.4 & 26.1 & 29.5 & -4.7 & 48.0 \\
\hline $1976-80$ & 6.7 & 21.0 & 27.7 & 29.5 & -2.3 & 34.4 \\
\hline 1981-85 & 6.7 & 22.7 & 29.3 & 32.6 & -4.9 & 36.5 \\
\hline$\underline{1986-90}$ & 6.3 & 22.5 & 28.7 & 33.7 & -5.1 & 23.3 \\
\hline \multirow[t]{2}{*}{$\underline{1991-96}$} & 5.4 & 20.2 & 25.5 & 29.7 & -3.3 & 26.4 \\
\hline & & \multicolumn{5}{|c|}{ HIGH-INCOME COUNTRIES } \\
\hline$\underline{1970-75}$ & 2.5 & 24.0 & 26.7 & 27.4 & -2.4 & 22.9 \\
\hline$\underline{1976-80}$ & 3.0 & 26.5 & 29.5 & 32.6 & -4.4 & 27.4 \\
\hline 1981-85 & 3.9 & 28.4 & 32.3 & 36.8 & -5.3 & 24.6 \\
\hline 1986-90 & 3.9 & 28.4 & 32.3 & 36.8 & -5.3 & 24.6 \\
\hline 1991-96 & 3.7 & 29.8 & 33.5 & 37.1 & -3.2 & 40.5 \\
\hline
\end{tabular}




\section{TABLE 3: The Structure of Taxation}

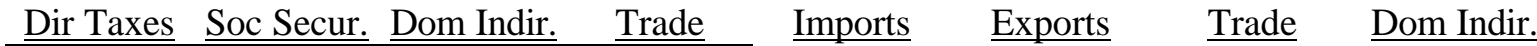
(\% of Total Tax Revenue)

\begin{tabular}{|c|c|c|c|c|c|c|c|c|}
\hline \multirow[b]{2}{*}{$\underline{1970-75}$} & \multicolumn{8}{|c|}{ LOW-INCOME COUNTRIES } \\
\hline & 26.1 & 2.0 & 29.3 & 40.8 & 18.1 & 6.3 & 11.1 & 5.84 \\
\hline$\underline{1976-80}$ & 25.2 & 2.5 & 28.3 & 39.3 & 17.3 & 7.5 & 10.6 & 7.86 \\
\hline$\underline{1981-85}$ & 25.5 & 2.4 & 32.0 & 37.0 & 17.7 & 6.3 & 10.2 & 6.78 \\
\hline$\underline{1986-90}$ & 27.0 & 1.6 & 33.5 & 35.1 & 18.9 & 5.1 & 9.9 & 7.72 \\
\hline \multirow[t]{2}{*}{$\underline{1991-96}$} & 25.4 & 1.3 & 37.8 & 32.2 & 18.9 & 2.4 & 9.4 & 8.30 \\
\hline & \multicolumn{8}{|c|}{ LOWER MIDDLE-INCOME COUNTRIES } \\
\hline$\underline{1970-75}$ & 29.9 & 4.8 & 26.7 & 31.9 & 15.9 & 3.9 & 8.6 & 4.90 \\
\hline$\underline{1976-80}$ & 30.4 & 7.6 & 24.0 & 30.0 & 14.0 & 4.6 & 8.3 & 5.15 \\
\hline$\underline{1981-85}$ & 32.8 & 8.1 & 25.0 & 25.5 & 13.0 & 2.8 & 6.6 & 5.14 \\
\hline$\underline{1986-90}$ & 32.0 & 8.4 & 28.6 & 23.3 & 13.9 & 2.1 & 5.8 & 5.65 \\
\hline \multirow[t]{2}{*}{$\underline{1991-96}$} & 32.7 & 7.1 & 33.9 & 20.3 & 12.7 & 0.7 & 5.1 & 6.88 \\
\hline & \multicolumn{8}{|c|}{ UPPER MIDDLE-INCOME COUNTRIES } \\
\hline$\underline{1970-75}$ & 36.7 & 13.7 & 24.5 & 20.8 & 10.0 & 3.6 & 5.7 & 4.05 \\
\hline$\underline{1976-80}$ & 42.4 & 11.5 & 24.8 & 17.0 & 10.7 & 3.7 & 4.7 & 5.24 \\
\hline$\underline{1981-85}$ & 36.5 & 14.1 & 30.3 & 15.7 & 11.4 & 2.8 & 4.8 & 7.01 \\
\hline$\underline{1986-90}$ & 29.5 & 16.8 & 31.1 & 18.2 & 13.3 & 1.8 & 5.2 & 7.88 \\
\hline \multirow[t]{2}{*}{$1991-96$} & 32.4 & 14.8 & 33.8 & 15.9 & 12.0 & 0.6 & 3.6 & 6.95 \\
\hline & \multicolumn{8}{|c|}{ HIGH-INCOME COUNTRIES } \\
\hline$\underline{1970-75}$ & 37.7 & 17.9 & 30.8 & 7.5 & 6.0 & 0.4 & 2.7 & 5.53 \\
\hline$\underline{1976-80}$ & 37.4 & 21.4 & 29.7 & 6.3 & 4.9 & 0.3 & 2.0 & 7.87 \\
\hline$\underline{1981-85}$ & 37.7 & 22.1 & 30.3 & 4.9 & 3.9 & 0.2 & 1.6 & 8.48 \\
\hline$\underline{1986-90}$ & 37.9 & 21.0 & 31.6 & 3.8 & 3.5 & 0.1 & 1.3 & 8.31 \\
\hline 1991-96 & 36.1 & 24.4 & 31.4 & 2.3 & 2.4 & 0.0 & 0.8 & 8.00 \\
\hline
\end{tabular}


TABLE 4: Decomposition of Changes in Trade Tax Revenues Relative to GDP

\begin{tabular}{|c|c|c|c|c|c|c|c|}
\hline \multirow[t]{2}{*}{ Country Group } & \multirow[t]{2}{*}{$\underline{\text { Period }}$} & \multirow{2}{*}{$\frac{\frac{\text { Trade- }}{\text { to-GDP }}}{(\%)}$} & \multirow{2}{*}{$\frac{\text { Avg. Tax }}{\frac{\text { Rate }}{(\%)}}$} & $\frac{\text { Revenues- }}{\underline{\text { to-GDP }}}$ & $\frac{\text { Avg. Tax }}{\underline{\text { Rate }}}$ & $\begin{array}{l}\text { Trade- } \\
\text { to-GDP } \\
\end{array}$ & \multirow[t]{2}{*}{$\begin{array}{l}\text { "Laffer" } \\
\text { Effect }\end{array}$} \\
\hline & & & & \multicolumn{3}{|c|}{ (Avg. Annual Rate of Change, \%) } & \\
\hline \multirow[t]{2}{*}{ Low-Income SSA } & 2 & 60.4 & 9.5 & 0.4 & -0.1 & 0.5 & Yes \\
\hline & 3 & 60.1 & 8.1 & -1.6 & -1.6 & 0.0 & $\mathrm{x}$ \\
\hline \multirow[t]{2}{*}{ Other Low-Income } & 2 & 41.8 & 14.0 & 1.6 & 1.5 & 0.1 & $\mathrm{x}$ \\
\hline & 3 & 50.5 & 10.9 & -1.0 & -3.4 & 2.4 & $\mathrm{x}$ \\
\hline \multirow[t]{2}{*}{ Lower Middle-Income } & 2 & 53.6 & 6.8 & -1.7 & -2.4 & 0.7 & $\mathrm{x}$ \\
\hline & 3 & 59.8 & 5.6 & -1.5 & -2.9 & 1.4 & $\mathrm{x}$ \\
\hline \multirow[t]{2}{*}{ Upper Middle-Income } & 2 & 79.8 & 4.4 & -2.3 & -3.8 & 1.5 & $\mathrm{x}$ \\
\hline & 3 & 87.7 & 3.4 & -4.4 & -5.5 & 1.1 & $\mathrm{x}$ \\
\hline
\end{tabular}

Note: Average annual rates of change were computed from period means, where Periods 1, 2 and 3 stand for 1970-79, 1980-87 and 1988-1996 respectively. 
TABLE 4A: Decomposition of Changes in Trade Tax Revenues Relative to GDP

\begin{tabular}{|c|c|c|c|c|c|c|c|}
\hline \multirow[t]{2}{*}{ Country } & \multirow[t]{2}{*}{$\underline{\text { Period }}$} & \multirow{2}{*}{$\frac{\frac{\text { Trade- }}{\text { to-GDP }}}{(\%)}$} & \multirow{2}{*}{$\frac{\text { Avg. Tax }}{\frac{\text { Rate }}{(\%)}}$} & $\frac{\text { Revenues- }}{\underline{\text { to-GDP }}}$ & $\frac{\text { Avg. Tax }}{\text { Rate }}$ & $\begin{array}{l}\underline{\text { Trade- }} \\
\underline{\text { to-GDP }} \\
\end{array}$ & \multirow[t]{2}{*}{$\frac{\text { "Laffer" }}{\underline{\text { Effect }}}$} \\
\hline & & & & \multicolumn{3}{|c|}{ (Avg. Annual Rate of Change, \%) } & \\
\hline \multirow[t]{2}{*}{ Low-Income SSA } & 2 & 60.4 & 9.5 & 0.4 & -0.1 & 0.5 & \\
\hline & 3 & 60.1 & 8.1 & -1.6 & -1.6 & 0.0 & \\
\hline Burkina Faso & 2 & 42.5 & 9.7 & -2.0 & -3.4 & 1.4 & $\mathrm{x}$ \\
\hline Burundi & 3 & 32.7 & 11.6 & -1.8 & -2.1 & 0.4 & $\mathrm{x}$ \\
\hline Cameroon & 2 & 54.4 & 8.6 & -3.8 & -4.6 & 0.8 & $\mathrm{x}$ \\
\hline Cameroon & 3 & 37.0 & 7.1 & -6.8 & -2.3 & -4.5 & $\mathrm{x}$ \\
\hline Chad & 3 & 60.6 & 3.3 & -1.3 & 0.6 & -1.9 & Yes \\
\hline Congo, Dem. Rep. & 2 & 40.8 & 7.9 & -3.3 & -7.3 & 3.9 & $\mathrm{x}$ \\
\hline Congo, Dem. Rep. & 3 & 47.1 & 5.6 & -2.4 & -4.1 & 1.7 & $\mathrm{x}$ \\
\hline Ethiopia & 3 & 21.2 & 12.8 & -4.4 & -1.8 & -2.7 & $\mathrm{x}$ \\
\hline Gambia, The & 3 & 148.7 & 6.3 & -3.3 & -6.1 & 2.8 & $\mathrm{x}$ \\
\hline Ghana & 2 & 20.2 & 16.9 & -4.3 & 0.1 & -4.4 & Yes \\
\hline Ghana & 3 & 44.9 & 10.6 & 4.0 & -5.4 & 9.4 & Yes \\
\hline Kenya & 2 & 53.9 & 8.2 & 1.5 & 3.2 & -1.7 & $\mathrm{x}$ \\
\hline Kenya & 3 & 58.4 & 5.5 & -3.8 & -4.8 & 0.9 & $\mathrm{x}$ \\
\hline Lesotho & 2 & 153.6 & 17.0 & 6.2 & 2.3 & 3.9 & $\mathrm{x}$ \\
\hline Lesotho & 3 & 149.4 & 16.5 & -0.7 & -0.4 & -0.3 & $\mathrm{x}$ \\
\hline Malawi & 2 & 53.8 & 7.6 & 3.5 & 5.6 & -2.1 & $\mathrm{x}$ \\
\hline Malawi & 3 & 57.1 & 6.0 & -2.1 & -2.8 & 0.7 & $\mathrm{x}$ \\
\hline Mali & 2 & 51.2 & 5.7 & -1.1 & -4.3 & 3.2 & $\mathrm{x}$ \\
\hline Mali & 3 & 50.7 & 4.6 & -2.7 & -2.6 & -0.1 & $\mathrm{x}$ \\
\hline Niger & 2 & 62.9 & 8.4 & 3.1 & 1.6 & 1.5 & $\mathrm{x}$ \\
\hline Nigeria & 2 & 34.1 & 5.1 & -4.5 & -3.3 & -1.2 & $\mathrm{x}$ \\
\hline Rwanda & 2 & 40.8 & 13.3 & -0.9 & -3.1 & 2.3 & $\mathrm{x}$ \\
\hline Rwanda & 3 & 23.6 & 14.2 & -5.6 & 0.8 & -6.4 & Yes \\
\hline Senegal & 2 & 79.6 & 9.2 & 0.0 & -0.9 & 0.9 & Yes \\
\hline Sierra Leone & 2 & 65.0 & 5.7 & -7.5 & -7.6 & 0.1 & $\mathrm{x}$ \\
\hline Sierra Leone & 3 & 47.6 & 6.8 & -1.6 & 2.1 & -3.7 & Yes \\
\hline Sudan & 2 & 34.8 & 17.0 & -1.9 & -3.7 & 1.8 & $\mathrm{x}$ \\
\hline Togo & 2 & 101.1 & 8.7 & -1.4 & 0.3 & -1.7 & Yes \\
\hline Zambia & 2 & 74.9 & 5.1 & 7.1 & 8.4 & -1.3 & $\mathrm{x}$ \\
\hline Zambia & 3 & 73.7 & 5.5 & 0.6 & 0.8 & -0.2 & $\mathrm{x}$ \\
\hline Zimbabwe & 2 & 55.6 & 6.8 & 15.1 & 14.8 & 0.3 & $\mathrm{x}$ \\
\hline Zimbabwe & 3 & 71.3 & 7.3 & 3.8 & 0.8 & 2.9 & $\mathrm{x}$ \\
\hline \multirow[t]{2}{*}{$\underline{\text { Other Low-Income }}$} & 2 & 41.8 & 14.0 & 1.6 & 1.5 & 0.1 & \\
\hline & 3 & 50.5 & 10.9 & -1.0 & -3.4 & 2.4 & \\
\hline India & 2 & 15.3 & 21.2 & 4.7 & 3.3 & 1.4 & $\mathrm{x}$ \\
\hline India & 3 & 20.6 & 16.7 & 0.7 & -2.8 & 3.5 & Yes \\
\hline Pakistan & 2 & 34.9 & 15.2 & 0.9 & -0.3 & 1.3 & Yes \\
\hline Pakistan & 3 & 36.0 & 14.2 & -0.4 & -0.8 & 0.4 & $\mathrm{x}$ \\
\hline
\end{tabular}


TABLE 4A: Decomposition ... (contd.)

\begin{tabular}{|c|c|c|c|c|c|c|c|}
\hline \multirow[t]{2}{*}{ Country } & \multirow[t]{2}{*}{ Period } & \multirow{2}{*}{$\frac{\frac{\text { Trade- }}{\text { to-GDP }}}{(\%)}$} & \multirow{2}{*}{$\frac{\text { Avg. Tax }}{\frac{\text { Rate }}{(\%)}}$} & $\frac{\text { Revenues- }}{\underline{\text { to-GDP }}}$ & $\frac{\text { Avg. Tax }}{\text { Rate }}$ & $\begin{array}{r}\underline{\text { Trade- }} \\
\text { to-GDP } \\
\end{array}$ & \multirow[t]{2}{*}{$\begin{array}{l}\text { "Laffer" } \\
\underline{\text { Effect }}\end{array}$} \\
\hline & & & & \multicolumn{3}{|c|}{ (Avg. Annual Rate of Change, $\%$ ) } & \\
\hline Sri Lanka & 2 & 68.9 & 10.4 & -2.0 & -3.1 & 1.1 & $\mathrm{x}$ \\
\hline Sri Lanka & 3 & 70.6 & 6.9 & -4.6 & -4.9 & 0.3 & $\mathrm{x}$ \\
\hline Nicaragua & 2 & 48.0 & 9.0 & 2.9 & 6.4 & -3.5 & $\mathrm{x}$ \\
\hline Nicaragua & 3 & 74.8 & 5.9 & 0.2 & -5.0 & 5.2 & Yes \\
\hline \multirow[t]{2}{*}{$\underline{\text { Lower Middle-Income }}$} & 2 & 53.6 & 6.8 & -1.7 & -2.4 & 0.7 & \\
\hline & 3 & 59.8 & 5.6 & -1.5 & -2.9 & 1.4 & \\
\hline Botswana & 2 & 103.7 & 9.9 & -1.1 & -3.3 & 2.1 & $\mathrm{x}$ \\
\hline Botswana & 3 & 95.7 & 8.5 & -2.8 & -1.8 & -0.9 & $\mathrm{x}$ \\
\hline Namibia & 3 & 113.5 & 8.7 & 0.8 & 1.4 & -0.6 & $\mathrm{x}$ \\
\hline Swaziland & 3 & 165.8 & 7.1 & -4.7 & -5.9 & 1.2 & $\mathrm{x}$ \\
\hline Fiji & 3 & 115.9 & 5.6 & 0.3 & -2.5 & 2.9 & Yes \\
\hline Indonesia & 2 & 48.6 & 2.2 & -7.5 & -8.8 & 1.3 & $\mathrm{x}$ \\
\hline Indonesia & 3 & 49.8 & 1.8 & -2.0 & -2.2 & 0.3 & $\mathrm{x}$ \\
\hline Papua New Guinea & 2 & 94.3 & 5.0 & 4.5 & 3.7 & 0.8 & $\mathrm{x}$ \\
\hline Papua New Guinea & 3 & 92.2 & 6.3 & 2.4 & 2.7 & -0.3 & $\mathrm{x}$ \\
\hline Philippines & 2 & 49.6 & 6.1 & -2.6 & -3.4 & 0.8 & $\mathrm{x}$ \\
\hline Philippines & 3 & 68.1 & 6.6 & 4.7 & 1.0 & 3.7 & $\mathrm{x}$ \\
\hline Thailand & 2 & 50.8 & 6.4 & -0.9 & -2.7 & 1.8 & $\mathrm{x}$ \\
\hline Thailand & 3 & 77.2 & 4.4 & 0.5 & -4.4 & 4.9 & Yes \\
\hline Egypt, Arab Rep. & 2 & 57.1 & 11.9 & -4.2 & -3.6 & -0.6 & $\mathrm{x}$ \\
\hline Egypt, Arab Rep. & 3 & 54.9 & 6.5 & -7.6 & -7.2 & -0.5 & $\mathrm{x}$ \\
\hline Jordan & 3 & 132.2 & 6.1 & 1.1 & -0.7 & 1.8 & Yes \\
\hline Morocco & 2 & 52.7 & 8.0 & 1.5 & 0.3 & 1.2 & $\mathrm{x}$ \\
\hline Morocco & 3 & 54.9 & 8.3 & 0.9 & 0.4 & 0.5 & $\mathrm{x}$ \\
\hline Tunisia & 2 & 77.1 & 11.5 & 3.2 & 1.2 & 2.0 & $\mathrm{x}$ \\
\hline Tunisia & 3 & 89.0 & 9.4 & -0.7 & -2.4 & 1.7 & $\mathrm{x}$ \\
\hline Bolivia & 3 & 42.2 & 2.7 & -6.2 & -8.6 & 2.4 & $\mathrm{x}$ \\
\hline Colombia & 2 & 27.8 & 7.2 & -2.1 & -1.3 & -0.8 & $\mathrm{x}$ \\
\hline Colombia & 3 & 33.4 & 5.5 & -0.9 & -3.1 & 2.1 & $\mathrm{x}$ \\
\hline Costa Rica & 2 & 71.1 & 6.6 & 2.9 & 2.5 & 0.5 & $\mathrm{x}$ \\
\hline Costa Rica & 3 & 77.5 & 6.8 & 1.3 & 0.3 & 1.0 & $\mathrm{x}$ \\
\hline Dominican Rep. & 2 & 47.9 & 7.9 & -6.6 & -6.3 & -0.4 & $\mathrm{x}$ \\
\hline Dominican Rep. & 3 & 65.9 & 9.2 & 5.5 & 1.8 & 3.8 & $\mathrm{x}$ \\
\hline Ecuador & 2 & 57.7 & 3.7 & -6.1 & -4.6 & -1.5 & $\mathrm{x}$ \\
\hline El Salvador & 2 & 54.0 & 7.2 & -2.9 & -0.6 & -2.3 & $\mathrm{x}$ \\
\hline El Salvador & 3 & 47.9 & 3.9 & -8.5 & -7.1 & -1.4 & $\mathrm{x}$ \\
\hline Guatemala & 2 & 34.5 & 5.7 & -5.2 & -1.9 & -3.3 & $\mathrm{x}$ \\
\hline Guatemala & 3 & 41.9 & 4.4 & -0.6 & -2.9 & 2.3 & $\mathrm{x}$ \\
\hline Jamaica & 2 & 97.9 & 2.0 & 1.6 & -1.1 & 2.7 & Yes \\
\hline Panama & 3 & 175.9 & 1.4 & -1.0 & -3.5 & 2.4 & $\mathrm{x}$ \\
\hline
\end{tabular}


TABLE 4A: Decomposition ... (contd.)

\begin{tabular}{|c|c|c|c|c|c|c|c|}
\hline \multirow[t]{2}{*}{ Country } & \multirow[t]{2}{*}{$\underline{\text { Period }}$} & \multirow{2}{*}{$\frac{\frac{\text { Trade- }}{\text { to-GDP }}}{(\%)}$} & \multirow{2}{*}{$\frac{\text { Avg. Tax }}{\frac{\text { Rate }}{(\%)}}$} & $\frac{\text { Revenues- }}{\underline{\text { to-GDP }}}$ & $\frac{\text { Avg. Tax }}{\underline{\text { Rate }}}$ & $\begin{array}{l}\underline{\text { Trade- }} \\
\text { to-GDP } \\
\end{array}$ & \multirow[t]{2}{*}{$\frac{\text { "Laffer" }}{\underline{\text { Effect }}}$} \\
\hline & & & & \multicolumn{3}{|c|}{ (Avg. Annual Rate of Change, $\%$ ) } & \\
\hline Paraguay & 2 & 39.2 & 3.9 & -7.4 & -9.0 & 1.6 & $\mathrm{x}$ \\
\hline Paraguay & 3 & 53.6 & 3.7 & 3.2 & -0.5 & 3.7 & Yes \\
\hline Peru & 2 & 35.2 & 9.0 & 1.2 & 1.3 & 0.0 & $\mathrm{x}$ \\
\hline Peru & 3 & 25.5 & 5.4 & -9.9 & -6.1 & -3.8 & $\mathrm{x}$ \\
\hline Venezuela & 2 & 40.7 & 7.6 & 8.8 & 10.4 & -1.6 & $\mathrm{x}$ \\
\hline Venezuela & 3 & 53.9 & 3.2 & -7.0 & -10.3 & 3.3 & $\mathrm{x}$ \\
\hline Poland & 3 & 47.4 & 6.1 & 0.4 & -2.9 & 3.3 & Yes \\
\hline Turkey & 2 & 26.8 & 3.9 & -8.8 & -17.0 & 8.2 & $\mathrm{x}$ \\
\hline Turkey & 3 & 35.1 & 2.1 & -4.3 & -7.5 & 3.2 & $\mathrm{x}$ \\
\hline \multirow[t]{2}{*}{$\underline{\text { Upper Middle-Income }}$} & 2 & 79.8 & 4.4 & -2.3 & -3.8 & 1.5 & \\
\hline & 3 & 87.7 & 3.4 & -4.4 & -5.5 & 1.1 & \\
\hline Mauritius & 2 & 106.0 & 10.0 & 3.7 & 3.4 & 0.3 & $\mathrm{x}$ \\
\hline Mauritius & 3 & 129.0 & 7.3 & -1.4 & -3.7 & 2.3 & $\mathrm{x}$ \\
\hline Seychelles & 3 & 118.9 & 20.2 & 3.8 & 3.8 & 0.0 & $\mathrm{x}$ \\
\hline South Africa & 2 & 54.0 & 1.6 & -3.6 & -3.2 & -0.4 & $\mathrm{x}$ \\
\hline South Africa & 3 & 47.2 & 2.3 & 2.6 & 4.2 & -1.6 & $\mathrm{x}$ \\
\hline Malaysia & 2 & 109.3 & 5.7 & -0.9 & -3.4 & 2.5 & $\mathrm{x}$ \\
\hline Malaysia & 3 & 156.9 & 2.6 & -5.1 & -9.4 & 4.3 & $\mathrm{x}$ \\
\hline Oman & 3 & 85.4 & 1.1 & 1.6 & 1.9 & -0.3 & $\mathrm{x}$ \\
\hline Argentina & 3 & 16.1 & 7.5 & -1.3 & -2.0 & 0.8 & $\mathrm{x}$ \\
\hline Barbados & 2 & 124.7 & 3.6 & -3.7 & -3.8 & 0.1 & $\mathrm{x}$ \\
\hline Barbados & 3 & 98.7 & 3.8 & -2.0 & 0.8 & -2.8 & Yes \\
\hline Brazil & 3 & 15.3 & 3.3 & -5.4 & -2.9 & -2.5 & $\mathrm{x}$ \\
\hline Chile & 2 & 50.2 & 4.2 & -2.2 & -6.0 & 3.9 & $\mathrm{x}$ \\
\hline Chile & 3 & 59.2 & 3.6 & 0.1 & -1.8 & 2.0 & Yes \\
\hline Mexico & 2 & 26.6 & 3.1 & -5.1 & -9.9 & 4.8 & $\mathrm{x}$ \\
\hline Mexico & 3 & 37.8 & 2.4 & 1.1 & -3.1 & 4.1 & Yes \\
\hline Trinidad & 2 & 84.1 & 3.3 & -0.6 & -0.2 & -0.4 & $\mathrm{x}$ \\
\hline Trinidad & 3 & 85.4 & 2.4 & -3.6 & -3.8 & 0.2 & $\mathrm{x}$ \\
\hline Uruguay & 2 & 40.9 & 6.9 & 3.3 & 1.4 & 1.9 & $\mathrm{x}$ \\
\hline Uruguay & 3 & 42.6 & 4.4 & -4.8 & -5.3 & 0.5 & $\mathrm{x}$ \\
\hline Greece & 2 & 39.6 & 1.1 & -12.4 & -14.4 & 2.0 & $\mathrm{x}$ \\
\hline Greece & 3 & 44.0 & 0.1 & -32.7 & -33.9 & 1.2 & $\mathrm{x}$ \\
\hline Hungary & 3 & 66.0 & 4.5 & -1.9 & 0.2 & -2.1 & Yes \\
\hline Malta & 2 & 162.9 & 4.5 & -2.0 & -1.8 & -0.2 & $\mathrm{x}$ \\
\hline Malta & 3 & 175.9 & 4.9 & 1.8 & 0.9 & 0.9 & $\mathrm{x}$ \\
\hline
\end{tabular}

Note: Average annual rates of change were computed from period means, where Periods 1, 2 and 3 stand for 1970-79, 1980-87 and 1988-1996 respectively. 


\section{TABLE 5: Public Debt, Interest and Investment}

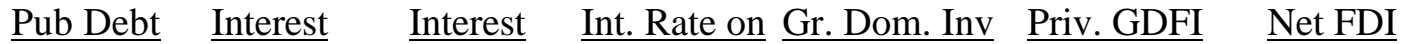

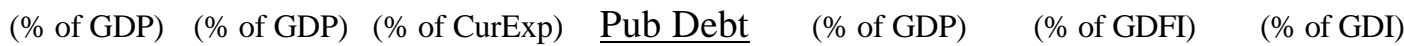

\begin{tabular}{|c|c|c|c|c|c|c|c|}
\hline \multicolumn{8}{|c|}{ LOW-INCOME COUNTRIES } \\
\hline$\underline{1970-75}$ & 34.6 & 1.1 & 5.1 & 3.6 & 17.7 & 65.4 & 3.5 \\
\hline$\underline{1976-80}$ & 63.3 & 2.5 & 9.8 & 5.1 & 19.5 & 46.4 & 2.8 \\
\hline$\underline{1981-85}$ & 50.9 & 1.5 & 6.1 & 3.9 & 20.8 & 50.4 & 3.2 \\
\hline$\underline{1986-90}$ & 87.3 & 2.8 & 11.6 & 5.2 & 19.3 & 50.5 & 2.4 \\
\hline$\underline{1991-96}$ & 98.4 & 3.6 & 15.5 & 3.9 & 20.7 & 55.0 & 7.3 \\
\hline \multicolumn{8}{|c|}{ LOWER MIDDLE-INCOME COUNTRIES } \\
\hline$\underline{1970-75}$ & 21.4 & 0.8 & 3.8 & 3.7 & 23.8 & 64.0 & 4.4 \\
\hline$\underline{1976-80}$ & 23.9 & 1.3 & 5.2 & 4.3 & 27.5 & 59.0 & 4.1 \\
\hline 1981-85 & 45.2 & 2.2 & 8.8 & 5.1 & 24.2 & 56.3 & 3.9 \\
\hline$\underline{1986-90}$ & 48.6 & 2.5 & 11.4 & 7.2 & 22.7 & 63.1 & 3.7 \\
\hline 1991-96 & 46.3 & 2.7 & 12.0 & 6.6 & 23.6 & 66.4 & 8.3 \\
\hline \multicolumn{8}{|c|}{ UPPER MIDDLE-INCOME COUNTRIES } \\
\hline$\underline{1970-75}$ & 24.6 & 1.2 & 4.8 & 4.5 & 25.7 & 62.7 & 6.2 \\
\hline$\underline{1976-80}$ & 28.0 & 1.5 & 5.6 & 5.5 & 27.2 & 62.7 & 6.3 \\
\hline 1981-85 & 35.4 & 2.9 & 10.8 & 12.6 & 23.3 & 65.4 & 5.6 \\
\hline$\underline{1986-90}$ & 45.8 & 5.2 & 16.9 & 10.0 & 21.4 & 73.0 & 6.8 \\
\hline$\underline{1991-96}$ & 45.7 & 4.3 & 14.5 & 7.8 & 21.1 & 76.2 & 10.7 \\
\hline \multicolumn{8}{|c|}{ HIGH-INCOME COUNTRIES } \\
\hline$\underline{1970-75}$ & 27.8 & 1.4 & 4.7 & 10.8 & 26.8 & 81.6 & 5.5 \\
\hline $1976-80$ & 37.5 & 2.2 & 6.5 & 6.5 & 26.0 & 78.1 & 3.9 \\
\hline 1981-85 & 52.0 & 4.1 & 10.4 & 8.1 & 23.7 & 75.2 & 3.9 \\
\hline$\underline{1986-90}$ & 51.4 & 4.6 & 12.2 & 8.6 & 23.3 & 79.3 & 6.8 \\
\hline 1991-96 & 50.8 & 4.1 & 10.6 & 7.2 & 22.3 & 80.7 & 8.4 \\
\hline
\end{tabular}


TABLE 6: Liberalization, Fiscal Impact and Accumulation in Developing Countries

\begin{tabular}{|c|c|c|c|c|c|c|c|c|}
\hline \multirow[t]{3}{*}{ Country Group } & \multirow[t]{3}{*}{ Period } & Trade- & Interest & Fiscal & Gov. Educ & Gov. Cap. & Gr. Dom. & \multirow{3}{*}{$\begin{array}{l}\text { PC Income } \\
\text { Avg. Ann. } \\
\text { Growth (\%) }\end{array}$} \\
\hline & & Tax Rev. & Expend. & $\underline{\text { Squeeze }}$ & Expend. & Expend. & Invest. & \\
\hline & & \multicolumn{6}{|c|}{ (Change between periods, $\%$ of GDP) } & \\
\hline \multirow[t]{2}{*}{ Low-Income SSA } & 2 & 0.4 & 1.4 & -1.1 & . & 0.9 & -1.4 & -0.6 \\
\hline & 3 & -0.7 & 0.9 & -1.6 & -0.1 & -1.1 & 1.7 & 2.7 \\
\hline \multirow[t]{2}{*}{ Other Low-Income } & 2 & 0.3 & 1.4 & -1.2 & . & 3.1 & 4.3 & 0.5 \\
\hline & 3 & -0.6 & 1.2 & -1.7 & 0.0 & -2.8 & 0.7 & 3.1 \\
\hline \multirow[t]{2}{*}{ Lower Middle-Income } & 2 & -0.4 & 1.5 & -1.9 & . & -1.2 & -1.0 & 1.6 \\
\hline & 3 & -0.4 & 0.6 & -1.0 & 0.2 & -1.2 & -0.8 & 5.6 \\
\hline \multirow[t]{2}{*}{ Upper Middle-Income } & 2 & -0.1 & 1.6 & -1.7 & . & -0.7 & -1.8 & 3.9 \\
\hline & 3 & 0.1 & 1.8 & -1.7 & 0.2 & -1.5 & -1.5 & 3.9 \\
\hline
\end{tabular}

Note: Change between periods was computed from period means, where Periods 1, 2 and 3 stand for 1970-79, 1980-87 and 1988-1996 respectively. 
TABLE 6A: Liberalization, Fiscal Impact and Accumulation in Developing Countries

\begin{tabular}{|c|c|c|c|c|c|c|c|c|}
\hline \multirow[t]{2}{*}{ Country } & \multirow[t]{2}{*}{$\underline{\text { Period }}$} & $\begin{array}{c}\underline{\text { Trade- }} \\
\text { Tax Rev. }\end{array}$ & $\begin{array}{l}\text { Interest } \\
\text { Expend. }\end{array}$ & $\begin{array}{c}\underline{\text { Fiscal }} \\
\text { Squeeze } \\
\end{array}$ & $\begin{array}{l}\text { Gov. Educ } \\
\text { Expend. }\end{array}$ & $\begin{array}{l}\text { Gov. Cap. } \\
\text { Expend. }\end{array}$ & $\frac{\text { Gr. Dom. }}{\text { Invest. }}$ & \multirow{2}{*}{$\begin{array}{r}\frac{\text { PC Income }}{\text { Avg. Ann. }} \\
\text { Growth (\%) }\end{array}$} \\
\hline & & \multicolumn{6}{|c|}{ (Change between periods, $\%$ of GDP) } & \\
\hline Low-Income SSA & 2 & 0.4 & 1.4 & -1.1 & . & 0.9 & -1.4 & -0.6 \\
\hline & 3 & -0.7 & 0.9 & -1.6 & -0.1 & -1.1 & 1.7 & 2.7 \\
\hline Burkina Faso & 2 & -0.8 & 0.2 & -1.0 & . & 0.0 & -1.9 & -0.9 \\
\hline Burundi & 3 & -0.6 & 1.0 & -1.7 & 1.1 & -0.1 & -3.9 & 1.2 \\
\hline Cameroon & 2 & -1.9 & 0.0 & -1.9 & . & 2.7 & 3.6 & -0.3 \\
\hline Cameroon & 3 & -2.1 & 1.6 & -3.7 & 0.1 & -4.4 & -8.5 & 4.1 \\
\hline Chad & 3 & -0.2 & 0.1 & -0.3 & . & -1.9 & 6.4 & 4.7 \\
\hline Congo, Dem. Rep. & 2 & -1.1 & 0.6 & -1.8 & . & -0.3 & -5.3 & -1.6 \\
\hline Congo, Dem. Rep. & 3 & -0.6 & -0.3 & -0.2 & . & -1.1 & -2.9 & -0.6 \\
\hline Ethiopia & 3 & -1.2 & 0.4 & -1.6 & . & -0.5 & 2.0 & 0.5 \\
\hline Gambia, The & 2 & 1.5 & 0.8 & 0.8 & . & 3.8 & 7.6 & . \\
\hline Gambia, The & 3 & -3.1 & 3.0 & -6.1 & 0.2 & -5.0 & -1.0 & 12.4 \\
\hline Ghana & 2 & -1.6 & -0.2 & -1.4 & . & -2.4 & -3.1 & -0.2 \\
\hline Ghana & 3 & 1.4 & 0.3 & 1.1 & 0.2 & 1.3 & 8.0 & 4.9 \\
\hline Kenya & 2 & 0.6 & 2.1 & -1.6 & - & -0.4 & 0.4 & 0.4 \\
\hline Kenya & 3 & -1.2 & 2.9 & -4.1 & -0.6 & 0.1 & -2.4 & 2.9 \\
\hline Lesotho & 2 & 11.2 & 3.6 & 7.5 & . & 19.0 & 22.0 & 0.3 \\
\hline Lesotho & 3 & -1.6 & 1.1 & -2.6 & -0.1 & -7.4 & 34.6 & 0.7 \\
\hline Liberia & 2 & -0.2 & 2.9 & -3.1 & . & -2.3 & -11.5 & . \\
\hline Liberia & 3 & 0.4 & -0.5 & 0.9 & . & -3.2 & . & 0.3 \\
\hline Malawi & 2 & 1.1 & 3.4 & -2.3 & . & 1.6 & -9.0 & -0.6 \\
\hline Malawi & 3 & -0.7 & -0.4 & -0.3 & 0.0 & -2.3 & -0.9 & 3.8 \\
\hline Mali & 2 & -0.3 & 0.5 & -0.8 & . & -0.1 & 0.4 & -0.7 \\
\hline Mali & 3 & -0.6 & 0.3 & -0.9 & -1.6 & -0.4 & 6.6 & 2.4 \\
\hline Niger & 2 & 1.3 & 0.2 & 1.1 & . & 3.5 & 0.7 & -1.0 \\
\hline Nigeria & 2 & -0.9 & 5.5 & -6.4 & . & 0.3 & -6.8 & -0.8 \\
\hline Rwanda & 2 & -0.4 & 0.1 & -0.5 & . & 1.4 & 4.0 & -0.7 \\
\hline Rwanda & 3 & -2.1 & 1.1 & -3.2 & 0.8 & 1.5 & -3.5 & -1.9 \\
\hline Senegal & 2 & 0.0 & 1.5 & -1.5 & . & 2.0 & -5.3 & -0.7 \\
\hline Sierra Leone & 2 & -3.6 & 0.3 & -3.8 & . & -0.1 & -2.0 & -1.3 \\
\hline Sierra Leone & 3 & -0.5 & 1.6 & -2.1 & -1.7 & -0.6 & -4.1 & 1.8 \\
\hline Sudan & 2 & -1.1 & 0.1 & -1.2 & . & -1.1 & -0.6 & -0.9 \\
\hline Togo & 2 & -1.2 & 3.4 & -4.6 & . & -11.7 & -7.8 & -0.5 \\
\hline Zambia & 2 & 1.8 & 0.3 & 1.5 & - & 0.2 & -12.8 & -0.4 \\
\hline Zambia & 3 & 0.2 & 0.0 & 0.2 & -1.4 & 4.8 & -4.1 & 2.3 \\
\hline Zimbabwe & 2 & 2.8 & 2.1 & 0.8 & . & 0.4 & 1.0 & 0.2 \\
\hline Zimbabwe & 3 & 1.4 & 1.9 & -0.5 & 1.5 & 1.3 & -0.8 & 3.8 \\
\hline
\end{tabular}


TABLE 6A: Liberalization ... (contd.)

\begin{tabular}{|c|c|c|c|c|c|c|c|c|}
\hline \multirow[t]{2}{*}{ Country } & \multirow[t]{2}{*}{$\underline{\text { Period }}$} & $\begin{array}{c}\text { Trade- } \\
\text { Tax Rev. }\end{array}$ & $\begin{array}{l}\text { Interest } \\
\text { Expend. }\end{array}$ & $\begin{array}{c}\text { Fiscal } \\
\text { Squeeze }\end{array}$ & $\begin{array}{c}\text { Gov. Educ } \\
\text { Expend. }\end{array}$ & $\frac{\text { Gov. Cap. }}{\text { Expend. }}$ & $\frac{\text { Gr. Dom. }}{\text { Invest. }}$ & \multirow{2}{*}{$\begin{array}{r}\text { PC Income } \\
\text { Avg. Ann. } \\
\text { Growth (\%) }\end{array}$} \\
\hline & & \multicolumn{6}{|c|}{ (Change between periods, $\%$ of GDP) } & \\
\hline Other Low-Income & 2 & 0.3 & 1.4 & -1.2 & & 3.1 & 4.3 & 0.5 \\
\hline & 3 & -0.6 & 1.2 & -1.7 & 0.0 & -2.8 & 0.7 & 3.1 \\
\hline India & 2 & 1.1 & 1.0 & 0.2 & . & 0.5 & 2.7 & 0.0 \\
\hline India & 3 & 0.2 & 1.7 & -1.5 & 0.7 & -0.1 & 1.9 & 4.1 \\
\hline Pakistan & 2 & 0.4 & 1.0 & -0.6 & ${ }^{\circ}$ & -0.6 & 2.7 & 0.3 \\
\hline Pakistan & 3 & -0.2 & 2.6 & -2.8 & 0.4 & 1.0 & 0.4 & 3.9 \\
\hline Sri Lanka & 2 & -1.4 & 2.0 & -3.4 & . & 6.2 & 9.5 & 2.5 \\
\hline Sri Lanka & 3 & -2.3 & 1.3 & -3.6 & 0.4 & -6.9 & -2.9 & 3.7 \\
\hline Nicaragua & 2 & 1.0 & 1.8 & -0.8 & . & 6.3 & 2.1 & -0.8 \\
\hline Nicaragua & 3 & 0.1 & -0.9 & 1.0 & -1.7 & -5.2 & 3.2 & 0.7 \\
\hline Lower Middle-Income & 2 & -0.4 & 1.5 & -1.9 & -0.3 & -1.2 & -1.0 & 1.6 \\
\hline & 3 & -0.4 & 0.6 & -1.0 & 0.2 & -1.2 & -0.8 & 5.6 \\
\hline Botswana & 2 & -1.1 & 0.2 & -1.3 & -0.4 & -2.3 & -10.7 & 2.3 \\
\hline Botswana & 3 & -2.1 & -0.2 & -2.0 & 2.0 & -1.5 & -1.5 & 6.4 \\
\hline Namibia & 3 & 0.7 & -1.7 & 2.4 & 7.0 & -1.9 & 3.0 & 4.3 \\
\hline Swaziland & 2 & 2.0 & 0.9 & 1.2 & . & -1.0 & 1.3 & . \\
\hline Swaziland & 3 & -5.7 & 0.0 & -5.8 & 0.0 & -4.0 & -6.1 & 0.7 \\
\hline Fiji & 2 & -0.5 & 1.4 & -1.9 & . & -0.9 & 0.1 & . \\
\hline Fiji & 3 & 0.2 & 0.5 & -0.3 & -0.9 & -0.7 & -8.6 & 2.8 \\
\hline Indonesia & 2 & -1.0 & 1.0 & -2.0 & . & 2.6 & 4.8 & 1.3 \\
\hline Indonesia & 3 & -0.2 & 0.4 & -0.6 & -0.2 & -2.4 & 3.3 & 7.2 \\
\hline Papua New Guinea & 2 & 1.6 & 1.2 & 0.3 & & -1.9 & 0.0 & -0.4 \\
\hline Papua New Guinea & 3 & 1.1 & 0.2 & 0.9 & . & -0.2 & -1.8 & 5.8 \\
\hline Philippines & 2 & -0.8 & 1.6 & -2.4 & . & 0.5 & -3.9 & 1.0 \\
\hline Philippines & 3 & 1.5 & 3.0 & -1.5 & 1.1 & 0.3 & -0.8 & 4.0 \\
\hline Thailand & 2 & -0.3 & 1.2 & -1.5 & . & 0.1 & 2.5 & 3.5 \\
\hline Thailand & 3 & 0.2 & -1.1 & 1.3 & 0.2 & 0.0 & 11.2 & 9.6 \\
\hline Egypt, Arab Rep. & 2 & -3.1 & 1.1 & -4.2 & $\cdot$ & -2.6 & 4.4 & 0.4 \\
\hline Egypt, Arab Rep. & 3 & -3.3 & 2.4 & -5.7 & -0.8 & -0.6 & -5.1 & 7.0 \\
\hline Jordan & 2 & -1.5 & 1.1 & -2.6 & & -4.8 & -4.7 & 0.8 \\
\hline Jordan & 3 & 0.7 & 2.5 & -1.8 & -1.8 & -3.4 & 0.4 & 8.3 \\
\hline Morocco & 2 & 0.5 & 2.6 & -2.1 & . & -1.9 & 2.2 & 0.8 \\
\hline Morocco & 3 & 0.3 & 1.3 & -0.9 & -0.4 & -1.4 & -2.7 & 2.6 \\
\hline Tunisia & 2 & 2.2 & 1.2 & 1.0 & . & 1.9 & 4.2 & 1.8 \\
\hline Tunisia & 3 & -0.5 & 1.1 & -1.7 & 0.5 & -3.5 & -5.0 & 7.2 \\
\hline Bolivia & 3 & -0.8 & 0.6 & -1.4 & 0.4 & 3.0 & 2.9 & 6.1 \\
\hline Colombia & 2 & -0.4 & 0.3 & -0.7 & . & -1.2 & 0.7 & 3.5 \\
\hline Colombia & 3 & -0.2 & 0.5 & -0.7 & 0.8 & -0.5 & 0.3 & 7.4 \\
\hline
\end{tabular}


TABLE 6A: Liberalization ... (contd.)

\begin{tabular}{|c|c|c|c|c|c|c|c|c|}
\hline \multirow[t]{2}{*}{$\underline{\text { Country }}$} & $\underline{\text { Period }}$ & $\begin{array}{c}\underline{\text { Trade- }} \\
\text { Tax Rev. }\end{array}$ & $\begin{array}{l}\text { Interest } \\
\text { Expend. }\end{array}$ & $\begin{array}{c}\underline{\text { Fiscal }} \\
\text { Squeeze }\end{array}$ & $\begin{array}{l}\text { Gov. Educ } \\
\text { Expend. }\end{array}$ & $\begin{array}{l}\text { Gov. Cap. } \\
\text { Expend. }\end{array}$ & $\frac{\text { Gr. Dom. }}{\text { Invest. }}$ & \multirow{2}{*}{$\begin{array}{r}\frac{\text { PC Income }}{\text { Avg. Ann. }} \\
\text { Growth (\%) }\end{array}$} \\
\hline & & \multicolumn{6}{|c|}{ (Change between periods, $\%$ of GDP) } & \\
\hline Costa Rica & 2 & 1.1 & 0.6 & 0.4 & . & -0.7 & 2.1 & 4.6 \\
\hline Costa Rica & 3 & 0.5 & 1.6 & -1.0 & -1.3 & -0.8 & 0.5 & 6.9 \\
\hline Dominican Republic & 2 & -3.1 & 0.4 & -3.5 & . & -2.7 & 0.2 & 1.2 \\
\hline Dominican Republic & 3 & 2.3 & 0.1 & 2.2 & -0.3 & 3.1 & 2.1 & 6.5 \\
\hline Ecuador & 3 & -0.8 & 2.1 & -2.9 & -1.8 & -0.8 & -1.5 & 7.1 \\
\hline El Salvador & 2 & -1.2 & 1.1 & -2.3 & . & -0.1 & -6.7 & 0.8 \\
\hline El Salvador & 3 & -2.0 & 0.1 & -2.1 & -1.7 & -0.5 & 4.1 & 3.8 \\
\hline Guatemala & 2 & -1.2 & 0.3 & -1.5 & -0.1 & 0.2 & -3.8 & 0.2 \\
\hline Guatemala & 3 & -0.1 & 0.3 & -0.4 & -0.3 & -1.3 & 1.7 & 4.0 \\
\hline Jamaica & 2 & 0.3 & 8.6 & -8.3 & . & -2.7 & -2.8 & 2.2 \\
\hline Panama & 2 & -0.5 & 2.9 & -3.5 & . & -3.5 & . & 1.5 \\
\hline Panama & 3 & -0.2 & -3.8 & 3.6 & 0.5 & -1.9 & -0.4 & 11.0 \\
\hline Paraguay & 2 & -1.4 & 0.2 & -1.6 & . & -0.6 & 4.3 & 0.9 \\
\hline Paraguay & 3 & 0.5 & 0.4 & 0.0 & 0.9 & -0.1 & -3.4 & 3.6 \\
\hline Peru & 2 & 0.3 & 1.8 & -1.5 & . & -0.1 & 5.2 & 0.2 \\
\hline Peru & 3 & -1.8 & -0.3 & -1.5 & . & -1.1 & -4.6 & 6.5 \\
\hline Suriname & 2 & -1.0 & 2.2 & -3.2 & . & -4.8 & -10.1 & . \\
\hline Venezuela & 2 & 1.7 & 1.7 & 0.0 & . & -1.2 & -12.9 & 2.0 \\
\hline Venezuela & 3 & -1.4 & 1.4 & -2.8 & -0.3 & -1.8 & -4.0 & 5.2 \\
\hline Poland & 3 & 0.1 & 3.1 & -3.0 & 0.6 & -1.2 & -3.8 & 4.7 \\
\hline Romania & 3 & 0.8 & 0.0 & 0.7 & 0.5 & -6.9 & -6.7 & 2.9 \\
\hline Turkey & 2 & -1.3 & 1.1 & -2.3 & . & -0.4 & 2.2 & 3.1 \\
\hline Turkey & 3 & -0.3 & 1.6 & -1.9 & 0.1 & -2.1 & 5.9 & 3.4 \\
\hline Upper Middle-Income & 2 & -0.1 & 1.6 & -1.7 & 0.7 & -0.7 & -1.8 & 3.9 \\
\hline & 3 & 0.1 & 1.8 & -1.7 & 0.2 & -1.5 & -1.5 & 3.9 \\
\hline Mauritius & 2 & 3.0 & 3.4 & -0.4 & . & -1.1 & -2.1 & 5.7 \\
\hline Mauritius & 3 & -1.1 & -2.1 & 0.9 & -0.7 & 0.3 & 7.7 & 5.0 \\
\hline Seychelles & 3 & 6.6 & 3.7 & 2.9 & -0.3 & -3.0 & -2.2 & 6.8 \\
\hline South Africa & 2 & -0.3 & 1.4 & -1.8 & . & -0.2 & -2.6 & 1.6 \\
\hline South Africa & 3 & 0.2 & 2.0 & -1.8 & 1.0 & -0.4 & -7.5 & 1.1 \\
\hline Malaysia & 2 & -0.5 & 2.9 & -3.4 & . & 3.1 & 5.9 & 3.9 \\
\hline Malaysia & 3 & -2.2 & -0.4 & -1.8 & -0.9 & -2.4 & 3.6 & 4.8 \\
\hline Oman & 2 & 0.2 & 0.1 & 0.1 & . & -6.1 & -2.7 & . \\
\hline Oman & 3 & 0.1 & 1.1 & -0.9 & 0.8 & -4.2 & -9.5 & 5.1 \\
\hline Argentina & 2 & 1.3 & 1.7 & -0.3 & . & 1.4 & -5.4 & 2.3 \\
\hline Argentina & 3 & -0.1 & -0.6 & 0.5 & 0.7 & -0.6 & -3.5 & 7.3 \\
\hline Barbados & 2 & -1.7 & 1.0 & -2.7 & . & -0.5 & -3.5 & 6.6 \\
\hline Barbados & 3 & -0.7 & 0.6 & -1.3 & 1.1 & -0.1 & -4.3 & -1.9 \\
\hline
\end{tabular}


TABLE 6A: Liberalization ... (contd.)

\begin{tabular}{|c|c|c|c|c|c|c|c|c|}
\hline Country & $\underline{\text { Period }}$ & $\begin{array}{c}\text { Trade- } \\
\text { Tax Rev. }\end{array}$ & $\begin{array}{l}\text { Interest } \\
\text { Expend. }\end{array}$ & $\begin{array}{c}\underline{\text { Fiscal }} \\
\text { Squeeze }\end{array}$ & $\begin{array}{c}\text { Gov. Educ } \\
\text { Expend. }\end{array}$ & $\begin{array}{l}\text { Gov. Cap. } \\
\text { Expend. }\end{array}$ & $\frac{\text { Gr. Dom. }}{\text { Invest. }}$ & $\frac{\text { PC Income }}{\text { Avg. Ann. }}$ \\
\hline & & & (Chang & between & periods, $\%$ & of GDP) & & Growth $(\%)$ \\
\hline Brazil & 3 & -0.3 & 11.5 & -11.8 & -0.5 & -0.6 & 1.1 & 5.7 \\
\hline Chile & 2 & -0.5 & -0.3 & -0.1 & . & -3.4 & -0.7 & 5.7 \\
\hline Chile & 3 & 0.0 & 0.2 & -0.2 & -1.5 & 0.2 & 9.2 & 5.5 \\
\hline Mexico & 2 & -0.5 & 7.2 & -7.6 & . & 0.6 & 0.7 & 2.1 \\
\hline Mexico & 3 & 0.1 & -2.4 & 2.5 & 0.8 & -1.9 & 0.1 & 6.1 \\
\hline Trinidad and Tobago & 2 & -0.2 & 0.1 & -0.3 & . & -0.7 & -2.8 & 3.9 \\
\hline Trinidad and Tobago & 3 & -0.7 & 4.5 & -5.3 & -1.1 & -9.4 & -10.1 & 1.7 \\
\hline Uruguay & 2 & 0.7 & 0.9 & -0.2 & . & -0.3 & -4.9 & 3.4 \\
\hline Uruguay & 3 & -0.9 & 0.4 & -1.4 & 0.4 & 0.2 & -2.8 & 2.4 \\
\hline Greece & 2 & -0.9 & 2.0 & -2.9 & 0.7 & -0.5 & -5.7 & 4.7 \\
\hline Greece & 3 & -0.4 & 6.6 & -7.0 & 0.2 & -0.5 & -2.4 & 5.9 \\
\hline Hungary & 3 & -0.5 & 1.5 & -2.0 & 1.4 & -2.5 & -4.5 & -4.6 \\
\hline Malta & 2 & -1.4 & -0.8 & -0.6 & . & -0.7 & 1.7 & 3.0 \\
\hline Malta & 3 & 1.2 & 0.6 & 0.6 & 1.2 & 1.9 & 2.1 & 7.8 \\
\hline
\end{tabular}

Note: Change between periods was computed from period means, where

Periods 1, 2 and 3 stand for 1970-79, 1980-87 and 1988-1996 respectively. 
TABLE 7: Trends in Social Investment

Public Expenditure on

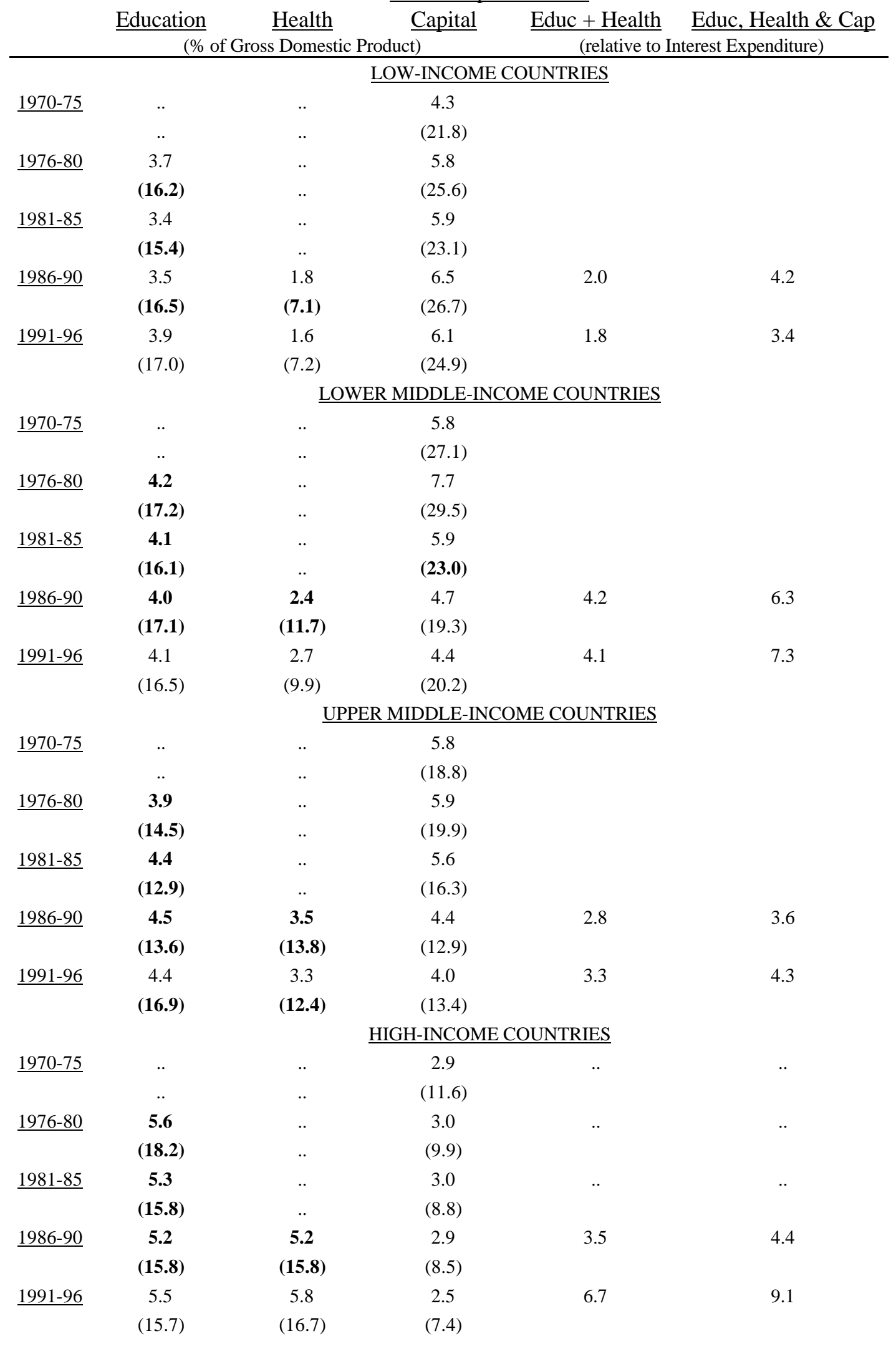

Notes Figures in parentheses are relative to public current expenditure.

Bold-faced figures indicate less than 30 observations. 